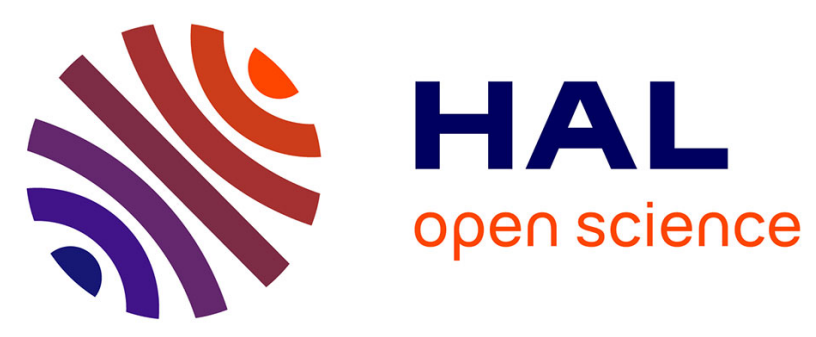

\title{
New structural data on Late Paleozoic tectonics in the Kyrgyz Tien Shan (Central Asian Orogenic Belt)
} Anthony Jourdon, Carole Petit, Yann Rolland, Chloé Loury, Nicolas Bellahsen, Stéphane Guillot, Laëtitia Le Pourhiet, Clément Ganino

\section{- To cite this version:}

Anthony Jourdon, Carole Petit, Yann Rolland, Chloé Loury, Nicolas Bellahsen, et al.. New structural data on Late Paleozoic tectonics in the Kyrgyz Tien Shan (Central Asian Orogenic Belt). Gondwana Research, 2017, 46, pp.57 - 78. 10.1016/j.gr.2017.03.004 . hal-01496108

\section{HAL Id: hal-01496108 https://hal.sorbonne-universite.fr/hal-01496108}

Submitted on 27 Mar 2017

HAL is a multi-disciplinary open access archive for the deposit and dissemination of scientific research documents, whether they are published or not. The documents may come from teaching and research institutions in France or abroad, or from public or private research centers.
L'archive ouverte pluridisciplinaire HAL, est destinée au dépôt et à la diffusion de documents scientifiques de niveau recherche, publiés ou non, émanant des établissements d'enseignement et de recherche français ou étrangers, des laboratoires publics ou privés. 


\title{
New structural data on Late Paleozoic tectonics in the Kyrgyz Tien Shan (Central Asian Orogenic Belt)
}

\author{
Anthony Jourdon ${ }^{\mathrm{a},{ }^{*}}$, Carole Petit ${ }^{\mathrm{a}}$, Yann Rolland ${ }^{\mathrm{a}}$, Chloé Loury ${ }^{\mathrm{a}}$, Nicolas Bellahsen ${ }^{\mathrm{b}}$, \\ Stéphane Guillot ${ }^{\mathrm{c}}$, Laëtitia Le Pourhiet ${ }^{\mathrm{b}}$ and Clément Ganino ${ }^{\mathrm{a}}$ \\ a- Université de Nice-Sophia Antipolis, CNRS, IRD, Observatoire de la Côte d'Azur, \\ Géoazur UMR 7329, 250 rue Albert Einstein, Sophia Antipolis 06560 Valbonne, \\ France. \\ b- ISTeP, Université Pierre et Marie Curie, Paris, France. \\ c- ISTerre, CNRS, Université Grenoble Alpes, 38041 Grenoble, France.
}

\section{Abstract}

The tectonic evolution of the Central Asian Orogenic Belt (CAOB) is characterized by the successive accretion of lithospheric blocks, leading to different interpretations about the polarity of subductions during the Paleozoic, the number of microplates and oceanic basins and the timing of tectonic events. This is especially the case in the Tien Shan area.

In this paper, we propose new structural maps and cross-sections of Middle and South Kyrgyz Tien Shan (MTS and STS respectively). These cross-sections highlight an overall dextral strike-slip shear zone in the MTS at the crustal scale and a North verging structure in the STS. These structures are Carboniferous in age and sealed by a late Carboniferous conglomerate, later overlain by Mesozoic and Cenozoic deposits. The STS exhibits two deformation phases: (1) a top-to-the-South normal shearing that can be related to subduction or exhumation dynamics and (2) a top to the North nappe stacking that we link to the late Paleozoic collisional events between the MTS and the Tarim block.

We propose a new interpretation of the tectonic evolution of the Kyrgyz Tien Shan during the Late Paleozoic collision. This model involves a partitioned collisional deformation in Late Carboniferous times, with an orthogonal collision to the south, between the Tarim and MTS, and a strike-slip regime to the north along a dextral E-W zone located between the MTS and the North Tien-Shan/ Kazakh platform, the so-called Nikolaev Line. The docking of the large Tarim Craton against the CAOB corresponds to a collision phase, which ended the longlived Paleozoic subduction history in the CAOB and was followed in the TS region by intense strike-slip deformation during the Permian.

Keywords: Tien Shan, Paleozoic, tectonics, structural geology.

\section{Introduction}

Orogens are classically divided into collisional orogens and accretionary orogens (e.g., Cawood et al., 2009; Kusky, 2011). The Alpine-Himalayan and Andean orogens are considered as typical examples of these two end-members, respectively (Demets et al., 1990; Guillot et al., 2003; Isaks, 1988; Le Fort, 1975). Collisional orogens commonly involve large cumulated strains both on the plate interface and within the colliding plates (e.g., Vanderhaeghe, 2012). They are the result of continental subduction and/or continental underthrusting and shortening, following the closure of an oceanic domain (Chen et al., 1999; 
Faccenda et al., 2008). In contrast, accretionary orogens develop on long-lasting oceanic subduction zones. As a result, they are composed of an amalgamation of material from the upper and lower plates associated with magmatic and metamorphic rocks (e.g., Cawood et al., 2009), and references therein). Accretion itself corresponds to a short-lived collisional phase (10-20 Ma) followed by a subduction jump, which favors the transfer of the plate interface to the opposite block boundary (e.g., Rolland et al., 2012). In such long-lived subduction systems, the subduction of oceanic ridges and transforms might induce large strike-slip motions in the upper plate with the detachment and oblique accretion of continental slices like in the NW American coast (Atwater, 1970; Furlong et al., 1989). Accretion can therefore be characterized by different kinematics from frontal collision to strike-slip motion.

The Central Asian Orogenic Belt (CAOB, e.g., (Windley et al., 2007; Xiao et al., 2014), also named "Altaids" (Şengör et al., 1993), results of the docking of numerous continental blocks and volcanic arcs against the Archean Siberian craton since the late Proterozoic and until the late Paleozoic (e.g., De Boisgrollier et al., 2009; Windley et al., 2007; Yarmolyuk et al., 2014). Although it has long been recognized as a typical example of an accretionary orogen, the collisional or accretionary nature of the CAOB is still a matter of debate. Indeed, it involves several large-scale collisions between important cratonic blocks, like the cratonized Kazakh platform and the Tarim craton (e.g., Xiao et al., 2014, 2013).The Paleozoic CAOB accretion history ended in Late Carboniferous with the collision of the large and rigid Tarim block with the Kazakh continent (e.g. Charvet et al., 2011; Windley et al., 2007)).

The Tien Shan (TS) belt (Figure 1) is a part of the CAOB and runs in a $\sim \mathrm{SW}-\mathrm{NE}$ direction over more than $2000 \mathrm{~km}$ from Uzbekistan to western China; it is located between the Kazakh and Junggar blocks to the North, and the Tarim craton to the South. Since about $30 \mathrm{Ma}$ (Macaulay et al., 2014; Sobel et al., 2006), this area has been a typical intracontinental collision zone undergoing a North-South shortening rate of $\sim 1.3 \mathrm{~cm} / \mathrm{yr}$ in response to the India-Asia convergence (Abdrakhmatov et al., 1996; Avouac et al., 1993). The present-day morphology and structural pattern of the TS belt largely result from this still on-going compression. Although it is widely admitted that most Cenozoic structures reactivate ancient thrusts and suture zones inherited from previous deformation stages (e.g., Buslov et al., 2007; Glorie et al., 2011), the amount of Paleozoic shortening is still largely unconstrained. In the following sections, we will only consider the part of the Paleozoic TS belt located east of the major dextral Talas Fergana Fault (TFF).

Lateral correlation of the different units constitutive of the TS belt remains difficult because of its complex geometry because it spreads over different countries. Another point of debate is the vergence of subduction zones that led to the final Paleozoic collage. There have been some attempts to synthesize the tectonic history of the TS belt based on unit correlation and available geochronological constraints (e.g., Loury et al., 2015; Wilhem et al., 2012; Windley et al., 2007; Xiao et al., 2013), but their interpretations differ in terms of timing and vergence of subduction zones.

In this paper, we present new field data in the Kyrgyz TS combined with published structural and geochronological results, which allow us to shed light on the style of deformation and unravel the Late Paleozoic tectonic history of the TS. 


\section{Geological Setting of the Tien Shan Belt}

\subsection{General structure of the Kyrgyz Tien Shan}

In Kyrgyzstan, the TS is characterized by three tectonic domains: the North, Middle and South TS (NTS, MTS and STS, respectively), squeezed between the more rigid lithospheres of the Kazakh platform and Tarim craton (Figure 1). Suture zones of different ages and kinematics separate all these domains. The NTS and MTS are located on both sides of a $\sim$ EW suture zone of middle Ordovician age, which worked as a broad strike-slip crustal zone during Permian times (e.g., Choulet et al., 2011). This broad wrench zone as well as the succession of individual strike-slip fault segments (when observed) are given the name "Nikolaev line" (e.g., Mikolaichuk et al., 1997; Windley et al., 2007). Further south, the MTS and STS are separated by a suture zone and an accretionary complex known as the At-BashiKokshaal suture zone, running E-W from Kyrgyzstan to NW China (e.g., Burtman, 2008; Glorie et al., 2011; Simonov et al., 2008).

The MTS progressively narrows eastward and disappears near the Kyrgyzstan/China border. Likewise, other blocks are only present in China and consequently, the tectonic units of the Chinese Tien Shan have a different nomenclature. There, the TS belt encompasses from North to South the Junggar, Yili-NTS, Central TS and South TS blocks (e.g., Gao et al., 1998).

From China to Kyrgyzstan, the At-Bashi-Kokshaal suture zone therefore marks there the junction between the Yili-NTS, and the CTS and STS blocks (Figure 1). Most of the sutures are reworked by Permian strike-slip faults (e.g., Laurent-Charvet et al., 2003, 2002; Wang et al., 2007a)). In particular, the prolongation of the strike-slip Nikolaev line in China runs along the NTS-CTS suture (Narat Fault, Figure 1).

\subsubsection{North Tien Shan}

The NTS is essentially composed of deformed Proterozoic to Cambrian sediments and volcanics highly intruded by magmatic bodies with calc-alkaline affinities, suggesting the presence of an active margin which lasted from the Ordovician in Kyrgyzstan (Bakirov and Maksumova, 2001; Bazhenov et al., 2003; Glorie et al., 2010; Konopelko et al., 2008; Kröner et al., 2014, 2012) to the Carboniferous in China (Wang et al., 2007b; Zhu et al., 2005).

In Kyrgyzstan, the active margin setting of the NTS is interpreted as the result of the northward subduction and closure of the Terskey Ocean during the Ordovician, eventually leading to the accretion of the MTS against the NTS in the Middle-Late Ordovician (Bakirov and Maksumova, 2001; Glorie et al., 2010; Lomize et al., 1997).

In China, observations on this margin two magmatic events are observed and correspond to the closure of two different oceanic domains: (i) the northward subduction of an oceanic domain located between the Tarim craton and the Yili-NTS block during the Ordovician (Allen et al., 1993; Chen et al., 1999; Gao et al., 2009, 1998; Qian et al., 2009; Windley et al., 1990; Xiao et al., 2014, 2004); (ii) the southward subduction of an oceanic domain located between the NTS and the Junggar block during the Carboniferous (Allen et al., 1993; Charvet et al., 2011; Wang et al., 2009, 2008; Windley et al., 1990).

The rest of the Paleozoic sedimentary cover of the NTS consists of Ordovician flyschs composed of volcanic tuffs, siltstones and sandstones sometimes overlain by Devonian 
volcanics (Bazhenov et al., 2003). Carboniferous (Late Tournaisian to Bashkirian) deposits in the NTS are clastic sediments composed of sandstones and siltstones with gypsum lenses characteristic of a shallow water to continental sedimentary environment (Mikolaichuk et al., 1997).

\subsubsection{Middle Tien Shan}

The MTS is a continental domain composed of a Neoproterozoic basement where the oldest observable rocks are characterized by an assemblage of metamorphosed sediments, amphibolites and orthogneisses. These rocks have been dated between $2.3 \mathrm{Ga}$ and $1.7 \mathrm{Ga}$ (Glorie et al., 2011; Keselev et al., 1982; Kiselev et al., 1993; Kröner et al., 2012). The basement of the MTS is overlain by Late Proterozoic tillites and diamectites and by a thick Paleozoic sedimentary cover principally composed of slates and carbonates from Cambrian to Carboniferous age. A regional-scale sedimentation hiatus is observed between the Late Ordovician and the Middle Devonian. The Carboniferous limestones of this sedimentary cover represent a carbonate platform sequence. An angular unconformity is also observed between the Early and Late Carboniferous (Osmonbetov et al., 1982). The Carboniferous carbonate platform of the MTS is thrusted towards the North over the clastic sequences of the NTS, and the thrusts are sealed by a conglomerate of Late Carboniferous age, which indicates a middle Bashkirian age for the thrust activity (Bazhenov et al., 2003).

\subsubsection{South and Central Tien Shan}

The STS represents the southernmost part of the TS and CAOB. In China, the STS is separated from the NTS by the At-Bashi-Kokshaal suture zone along which runs the Permian Narat strike-slip Fault (Yin et al., 1998). The CTS is separated from the STS by a strike-slip fault which may also be related to the Permian strike slip events (the Baluntai fault, LaurentCharvet et al., 2003; Wang et al., 2009; Yang et al., 2007, Figure 1). The STS is characterized by an accretionary complex and tectonic nappes, while the CTS is interpreted as a continental magmatic arc (Charvet et al., 2011; Gao et al., 2009; Liu et al., 2014; Wang et al., 2011; Xiao et al., 2014, 2013).

In China, the At-Bashi-Kokshaal suture zone is composed of metamorphic units with Pressure-Temperature (P-T) estimates of $28-30 \mathrm{kbar}$ and $520-540^{\circ} \mathrm{C}$ for the pressure peak, and $22-27 \mathrm{kbar}$ and $540-590^{\circ} \mathrm{C}$ for the temperature peak (Tian and Wei, 2013). The pressure peak has been dated with U-Pb method on zircon and rutile from $319 \mathrm{Ma}$ to $308 \mathrm{Ma}$ ( $\mathrm{Li}$ et al., 2011; Liu et al., 2014; Su et al., 2010; Zhang et al., 2009).

In Kyrgyzstan, the At-Bashi-Kokshaal suture is characterized by an accretionary complex composed of several metamorphosed units associated with a non-metamorphic ophiolite cropping out South of the At-Bashi city (Alekseev et al., 2007; Biske, 1996; Biske et al., 1985; Loury et al., 2015b). Recent geological mapping of the At-Bashi range evidenced a South-dipping top-to-the-North tectonic stack, with from bottom to top: (1) a low-grade unmetamorphosed ophiolite thrusted by (2) a greenschist to blueschist accretionary prism and (3) eclogite-facies continental and oceanic units (Loury et al., 2015b). A Gzhelian to Asselian conglomerate seals the deformation phase related to the exhumation of these high-pressure rocks (Baslakunov et al., 2007). 
To the East, near the Chinese boundary, Loury et al., (2015a) described in the STS a granulitic unit composed of an assemblage of pyroxene, feldspar, quartz and garnet overthrusting towards the North a low grade (greenschist facies) metamorphic sediments unit.

\subsection{Previously proposed models of TS accretion}

Different models were proposed to interpret and reconstitute the geological and tectonic history of the TS and CAOB (Kröner et al., 2014; Windley et al., 2007; Xiao et al., 2014). The formation of this kind of orogenic belt is closely associated to one or several oceanic subductions. However, for the TS, the number, polarity and duration of these subductions are still debated.

In Kyrgyzstan, most studies agree on the presence of a northward subduction of the Terskey ocean (Figure 1) during the Ordovician, responsible for the widespread calc-alkaline magmatism encountered in the NTS (Bakirov and Maksumova, 2001; Glorie et al., 2010; Kröner et al., 2013, 2012). Closure of the Terksey Ocean at $\sim 480$ Ma resulted in the collision between the MTS and the NTS (Lomize et al., 1997; Mikolaichuk et al., 1997). In China, this Early Paleozoic magmatism is found at the southern boundary of the Yili block which was then already a part of the NTS block (Wang et al., 2011, 2010). Because of the disappearance of the MTS block in China, the Ordovician active margin and suture are probably at least partially reworked there by the late Paleozoic CTS and STS/Tarim collision. Indeed, Gao et al. [2009] evidenced a long-lasting calc-alkaline magmatism from Early Ordovician to Permian times east of the MTS block, associated with HP metamorphism (Bazhenov et al., 2003; Lomize et al., 1997). They interpreted this magmatism as due to the simultaneous northward and southward closure of the Terskey Ocean between the CTS and NTS, and to the northward closure of the STS Ocean between the CTS and the Tarim (Figure 1). According to Gao et al. (2009), the CTS would be a continental block rifted away from the Tarim in a backarc setting, due to the southward subduction of the Terskey Ocean. This hypothesis of a Tarim affinity for CTS is supported by other authors (Lin et al., 2009; Wang et al., 2011, 2008) based on structural and magmatic arguments (Charvet et al., 2011, 2007, Dong et al., 2011, 2006, 2005; Guo et al., 2002; Laurent-Charvet, 2001; Ma et al., 1993; Zhong et al., 2014). However, Charvet et al. (2011) considered that the CTS rifted away from the Tarim margin during the Devonian following the South-dipping subduction of another ocean ("the South Tien Shan Ocean") beneath the Tarim.

The closure of the STS Ocean south of the CTS is another matter of debate. Some authors consider that it subducted towards the North under the NTS/CTS collided blocks, based on the observed N-S succession of magmatic arc (in the CTS block), accretionary complex (STS), and passive margin (Tarim) units (e.g., Chen et al., 1999; Gao et al., 2009; Liu et al., 2014; Xiao et al., 2014, 2013). Other authors rather propose a subduction towards the South, beneath the Tarim, based on the presence of subduction-related magmatic rocks on the North Tarim margin, and on numerous evidences of top-to-the-North deformations inside the STS accretionary complex (Charvet et al., 2011, 2007, Ge et al., 2014, 2012; Lei et al., 2011; Lin et al., 2013; Wang et al., 2016, 2007a). Most authors finally agree on a closure of the STS Ocean achieved at 310-340 Ma in China and 320 Ma in Kyrgyzstan.

Finally, in China, a last Paleozoic collision was related to the closure of the North Tien Shan ocean between the previously assembled CTS/STS/Tarim blocks and the Junggar block 
to the North (Allen et al., 1993; Charvet et al., 2011; Chen et al., 1999; Gao et al., 2009, 1998; Qian et al., 2009; Wang et al., 2009; Windley et al., 1990; Xiao et al., 2004).

\subsection{Post orogenic evolution of the Tien Shan}

After the last collisional event between the Tarim and the TS during the Carboniferous, the compressional regime was followed during the Permian by a strike-slip regime accommodated by large NW-SE and ENE-WSW wrench faults (e.g., the Talas Fergana Fault), which reactivated the suture zones of the TS belt (Alekseev et al., 2007; Jong et al., 2009; Konopelko et al., 2013; Rolland et al., 2013; Wang et al., 2007a). The Nikolaev Line as well as other large $\sim$ EW trending faults in the Chinese TS accommodated several hundreds of $\mathrm{km}$ of right-lateral shear (e.g. Choulet et al., 2011; Laurent-Charvet et al., 2003, 2002). A pervasive magmatic event occurred in all the TS and was characterized by granitic intrusions cross-cutting the Paleozoic structures and following the trace of the strike-slip faults (Alekseev et al., 2009; Biske et al., 2013; Chen et al., 2009; Seltmann et al., 2011; Wang et al., 2009). Mesozoic times are characterized by a long-lived erosion phase marked by a peneplain surface on which the Cenozoic formations were deposited (Abdrakhmatov et al., 2001; Jolivet et al., 2010; Macaulay et al., 2014). Despite this apparent tectonic quiescence, the dating of syn-kinematic pegmatites evidences a moderate tectonic activity of the TFF during the Late Triassic-Early Jurassic $\left(195 \pm 3 \mathrm{Ma},{ }^{40} \mathrm{Ar} /{ }^{39} \mathrm{Ar}\right.$ on muscovite; (Rolland et al., 2013).

\subsection{Cenozoic reactivation}

With respect to the Cenozoic deformation, the TS is a typical example of an intracontinental mountain range, which undergoes active compression in response to the India-Asia convergence (e.g. Avouac et al., 1993; Patriat and Achache, 1984; Sobel and Dumitru, 1997; Tapponnier et al., 1986). Geodetic data show that the TS currently accommodates of about $40 \%$ to $50 \%$ of the India-Asia convergence rate (i.e., $\sim 20 \mathrm{~mm} / \mathrm{yr}$ ) in the western part of the collided zone, including the shortening across the northern margin of the Tarim basin, for a total amount of crustal shortening of $200 \pm 50 \mathrm{~km}$ since max. $30 \mathrm{Ma}$ (Abdrakhmatov et al., 1996; Avouac et al., 1993; DeMets et al., 1994).

Cenozoic deformation has resulted in the development of five major mountain ranges delineating intra-mountainous molassic basins accumulating fluvial deposits. Cenozoic sediments overlie the late Mesozoic peneplain surface. A regional-scale angular unconformity can be traced in the landscape due to the higher erodibility of recent sediments compared to that of the Paleozoic bedrock. Low-temperature thermochronological data and sedimentary deposits suggest that uplift initiated $\sim 25 \mathrm{Ma}$ ago, but most of sediment deposition and relief exhumation started 11-12 Ma ago with a possible acceleration at 3-5 Ma (Abdrakhmatov et al., 2001; Bullen et al., 2001; Burbank et al., 1999; De Grave et al., 2004; Macaulay et al., 2014, 2013; Sobel et al., 2006; Thompson et al., 2002).

Tertiary tectonics is characterized by a dominant thick-skin tectonic with steep crustal ramps emerging between the ranges and the basins and accommodating basement exhumation on high-angle thrust faults (e.g. Macaulay et al., 2013). Moderate and more recent shallow ramp-flat faulting and a thin-skin tectonic propagating within the basins occurred in the late Quaternary (Thompson et al., 2002 and references therein, Goode et al., 2011). 
As exposed in the next sections, our field data confirm that Cenozoic deformation is localized principally along basins border faults and within the Cenozoic basins, whereas the inner parts of mountain ranges show uplifted remnants of flat-lying Cenozoic sediments.

\section{Structural analysis}

We present here a structural study of different stratigraphic and metamorphic units of the NTS, MTS and STS and their suture zones. Ages and lithological descriptions of sedimentary units in the MTS are after Karpovitch et al., (1964) and Lasovski and Mozolev, (1960).

\subsection{Structural geology of the Song-Kul zone}

The Song-Kul zone (Figure 2) spreads over a $20 \times 150 \mathrm{~km}$ area and is characterized by a general northward thrusting of the MTS Carboniferous carbonate platform over the NTS detrital Carboniferous formations.

In the NTS, the Early Paleozoic is represented by Ordovician rhyolites, sandstones and siltstones related to an active margin setting (Bakirov and Maksumova, 2001; Glorie et al., 2010; Konopelko et al., 2008; Kröner et al., 2014, 2012). A regional unconformity separates these Early Paleozoic formations from Serpukhovian sandstones with gypsum lenses, characteristic of the NTS deposition environment. Outcropping formations of the MTS are characterized by Upper Devonian sandstones overlain by a Tournaisian to Visean carbonate platform sequence, which thickness increases towards the south. Early Paleozoic sediments of the MTS do not crop out.

We discuss here in detail the nature and geometry of the contact between the MTS and the NTS. Three cross-sections through the Song-Kul zone are presented in the following section.

\subsubsection{Toktogul area}

The Toktogul area (Figure 3) is characterized by a northward thrusting of the MTS Tournaisian carbonate formation upon the Serpukhovian NTS clastic deposits. This NE-SW thrust is associated on the field and on geological maps with evidences of dextral strike-slip faulting on NW-SE vertical planes (Figure 3). It is sealed by flat-lying Cenozoic continental sandstones (Figure 3) overlying the Tournaisian limestones with an angular unconformity. It is difficult to precisely give an age to these Cenozoic sediments. Clearly, their deposition predated the formation of this mountain range, since they are now uplifted and deeply incised. By comparison with the onset of uplift of the Kyrgyz range north of the Toktogul area $\sim 11 \mathrm{Ma}$ ago (Sobel et al., 2006), they may be of Late Oligocene to Miocene age.

South of this thrust, a large rhombohedral basin is slightly thrusted upon Tournaisian formations along high angle reverse faults that look like inverted normal faults (Figure 3). The age of this basin is poorly constrained, but Jukov et al. (2008) consider its age as Devonian to Early Carboniferous, or as Late Carboniferous, on the basis of pollen assemblages. Its geometric shape on map suggests it could have been emplaced in a strike-slip context (i.e., as a pull-apart basin), but at present we can only speculate on its origin.

To the North, Serpukhovian sandstones of the NTS are also slightly thrusted along a dextral strike-slip fault over the Ordovician flysch, which is intensely folded.

On map, the geometry and kinematics of thrusts and normal faults is consistent with an EW dextral strike-slip deformation regime that prevailed during the end of the Early 
Carboniferous (Figure 2). This suggests that both the thrusting of Tournaisian formations of the MTS over the Serpukhovian formations of the NTS, and the possible opening of a pullapart basin can be roughly contemporaneous. Bazhenov et al. (2003) indicate that a Late Carboniferous conglomerate seals the northward thrusting of the MTS over the NTS and ascribes it a Bashkirian age, which is consistent with this interpretation.

\subsubsection{Central Song-Kul area}

In this area (Figure 4), Early Paleozoic formations crop out and are thrusted over a narrow E-W Cenozoic basin (Figure 5a). The border of this basin is strongly folded and reveals an anticline core composed of Jurassic gypsum formations (Figure 5b). Early Paleozoic rocks are represented by a thick rhyolitic series on which Serpukhovian sandstones with gypsum lenses are unconformably lying (Figure 5c). Deformation of the rhyolites and overlying sequences is characterized by long-wavelength upright folds (Figures 4 and 5) and top-to-the-North thrusts with moderate throw.

Gypsum layers interbedded in Serpukhovian sandstones allow the development of smallscale thrusts (Figure 5d), which may root at depth beneath the rhyolite series.

Hence, in this area, the only major visible deformation is the Cenozoic thrusting of the Ordovician rhyolites upon the Cenozoic basin (Figures 4 and 5a); there is no clear evidence of pre-Cenozoic deformation, although it is possible that a part of the moderate shortening observed in the Ordovician-Serpukhovian sequence is Paleozoic.

More to the South, the Tournaisian carbonate platform of the MTS is thrusted towards the North over these Ordovician and Serpukhovian formations of the NTS (Figure 4). Based on the interpretation of Bazhenov et al. (2003) and on the similarity of this area with the Toktogul section, we assume that this northward thrust is of middle Carboniferous age (Figure 3). However, we did not observe any post-tectonic unconformity that can definitely confirm this age in this area.

\subsubsection{Song-Kul cross-section}

This cross-section (Figure 6) is located entirely in the Carboniferous carbonate platform of the MTS. Devonian deposits are characterized by sandstones while the Carboniferous is represented by Tournaisian limestones overlain by siltstones and sandstones of Visean age.

To the South, Cenozoic sediments of the Naryn basin overlay an anticline limb of Tournaisian limestones, and are slightly folded. North of this anticline, Visean deposits crop out in a syncline in which top-to-the-South-East overturned folds are visible (Figure 6). North of this structure, Tournaisian limestones are thrusted over the Visean syncline and also display southward overturned folds. Beyond this thrusted and folded unit, a normal fault slightly offsets Tournaisian deposits (Figure 7a). Bedding measurements indicate that fold axes consistently trend NE-SW (Figure 6).

A marble slice delimited by two highly dipping tectonic contacts crops out north of this fold-and-thrust structure. It presents a well-developed $\mathrm{N} 60^{\circ} \mathrm{E}$ foliation with a $50^{\circ}$ to $60^{\circ}$ southward dip (Figure $7 \mathrm{~b}$ ). The stretching lineation associated with this foliation has a pitch of $38^{\circ} \mathrm{W}$, which gives a $\sim \mathrm{N} 220^{\circ} \mathrm{E}$ direction i.e., parallel to the fold axes in the TournaisianVisean cover. Asymmetric markers (boudins) show a top to the south-west normal sense of shear (Figure 7b). This oblique normal deformation can be associated with the exhumation of 
this marble unit in a strike-slip context with a NW-SE shortening and NE-SW stretching. To the North, this unit is thrusted northwards upon Lower Tournaisian limestones (Figure 7c). These limestones in turn overlay Devonian sandstones, where we could observe a minor shear zone probably associated with a decollement between both series.

Both large-scale fold axes in the Tournaisian-Visean sequences and ductile deformation of the marble units are thus compatible with a NW-SE shortening and a NE-SW stretching. We interpret this deformation as related to a $\sim \mathrm{E}-\mathrm{W}$ dextral strike slip deformational regime. The presence of the marble unit leads to several interpretations: (i) metamorphism and ductile deformation can be due to shear heating, so that the marbles could be highly deformed and metamorphosed Tournaisian limestones. (ii) alternatively, this unit can correspond to an older part of the Paleozoic cover, which was exhumed in the favor of the strike-slip fault zone. Unfortunately, there is no possibility to better constrain the depth at which these carbonates were deformed and metamorphosed.

\subsubsection{East Song-Kul area}

SE of Lake Song-Kul, a short NS valley crosses the Song-Kul zone and ends towards the North on the trace of a major strike-slip fault (often referred to as the Nikolaev Line, although, as explained above, this term has a more regional meaning). Basically, sediments of Ordovician to Carboniferous age are deformed by steep top-to-the-south thrusts and tight upright folds trending $\sim$ N80, sometimes accompanied by an almost vertical EW schistosity. More recent (Permian) intrusions following the trace of the fault caused high-temperature metamorphism in host (Carboniferous) sediments resulting in marbles formation.

Microtectonic measurements (bedding, schistosity, slickenslides, stretching lineations) on all these areas of the Song-Kul zone point out towards shortening and stretching directions oriented $\sim \mathrm{N} 135^{\circ} \mathrm{E}$ and $\sim \mathrm{N} 45^{\circ} \mathrm{E}$, respectively (Figure 6 ). Schistosity follows the general NESW axis direction of main folds, except close to the strike-slip fault where it trends more EW, i.e., parallel to the fault (Figure 8). Overall, the Song-Kul zone shows deformations compatible with a broad EW dextral strike-slip zone forming a positive flower structure, with fold and thrust axes trending between perpendicular to the shortening direction and parallel to the strike-slip fault.

\subsection{Structural geology of the At-Bashi region}

\subsubsection{Lithology}

The At-Bashi accretionary complex (Figure 9) crops out south of the Cenozoic At-Bashi basin and is characterized by a tectonic stack of metamorphic units thrusted towards the North. We describe them below, from bottom to top in their present structural position:

- In some places, a slice of metamorphic continental basement crops out at the foot of the At-Bashi ridge. It is composed of granitoids and gneisses presenting a greenschist facies imprint (Loury et al., 2015b) and interpreted as a part of the MTS basement (Alekseev et al., 2007).

- A dismembered non-metamorphic ophiolite unit has been observed in several places of the At-Bashi range (Alekseev et al., 2009), with serpentinites, gabbros and radiolarites. 
- A micaschist and gneiss unit bearing garnet, phengite and quartz underwent HighPressure (HP) metamorphic conditions $\left(500-660^{\circ} \mathrm{C}-20-25 \mathrm{kbar}\right)$ and is interpreted as a retrogressed eclogitic continental unit (Loury et al., 2015b). In some places, this HP continental unit overlays a metasedimentary unit containing lenses of mafic eclogites with similar metamorphic conditions (Loury et al., 2015b; Simonov et al., 2008; Tagiri et al., 1995).

- An accretionary wedge unit made of calcshists and sandstones of Silurian to Carboniferous age (Alekseev et al., 2007) and metabasite boudins, which recorded blueschist and greenschist facies metamorphism, constitutes the largest part of the AtBashi range (figure $10 \mathrm{~b}$ and $10 \mathrm{c}$ ).

- A thick pile of marbles of possible Silurian to Devonian protolith age (Burtman, 2008; Karpovitch et al., 1964) is generally observed on top of the accretionary wedge (figure 10d).

- A Late Carboniferous to Early Permian conglomerate with serpentines and eclogites pebbles unconformably overlies the former units (Alekseev et al., 2007).

Simonov et al. (2008) dated the At-Bashi HP units with the ${ }^{40} \mathrm{Ar} /{ }^{39} \mathrm{Ar}$ method on phengite at $327 \pm 4 \mathrm{Ma}$, and more recently Hegner et al., (2010) obtained Sm/Nd isochron age of $319 \pm 4$ $\mathrm{Ma}$ and a ${ }^{40} \mathrm{Ar} /{ }^{39} \mathrm{Ar}$ on phengite age of $316 \pm 3 \mathrm{Ma}$ interpreted as a crystallization age at the pressure peak and a cooling age, respectively.

Cenozoic deposits of the Naryn and At-Bashi basins rest with an angular unconformity upon Paleozoic formations.

\subsubsection{New structural observations and of the MTS and STS in the At-Bashi region}

Between the Cenozoic Naryn and At-Bashi basins (Figure 2), Paleozoic sediments of the MTS crop out along an elongated discontinuous range made of en-echelon segments, which are uplifted and tilted by Cenozoic E-W South verging thrusts.

The At-Bashi and Naryn basins themselves are characterized by a moderate deformation with long-wavelength folds and South-verging thrusts, which are rooted probably at the interface between Paleogene and Paleozoic formations (Figure 4). The MTS South of the Song-Kul zone and North of At-Bashi is largely covered by Cenozoic basins, which complicates the precise characterization of Paleozoic deformations.

The At-Bashi accretionary complex (Figure 9) is uplifted by a Cenozoic North-verging thrust over the At-Bashi basin. In the accretionary complex, the micaschist and gneiss unit is thrusted northward onto the ophiolitic unit, the latter being also thrusted northward over the metamorphic basement. The micaschist unit displays top-to-the-North ductile shear criteria (Figure 10a) associated with a top-to-the-South ductile shearing on a South-dipping normal shear zone separating this unit from the accretionary wedge (Figure 9). These deformations have been interpreted as resulting from the exhumation of this high grade metamorphic unit as further East in the Tash-Rabat area (Loury et al., 2015b).

In the accretionary wedge itself, the deformation is characterized by a pervasive $S_{1}$ schistosity that may develop on former bedding $\left(S_{0}\right)$ planes. These $S_{0}-S_{1}$ planes are intensely folded and associated with the development of an axial planar schistosity $\mathrm{S}_{2}$ globally trending NE-SW and dipping toward the North (Figure 9). The $S_{2}$ schistosity is moderately folded by a late deformation stage (Figure 9), which age is unconstrained. Shortening direction inferred 
from schistosity fold axes and lineations is approximately $\mathrm{N} 165^{\circ} \mathrm{E}$, i.e., rotated clockwise by $20^{\circ}$ with respect to the Song-Kul zone (Figure 9). Both schistosities $S_{1}$ and $S_{2}$ display similar kinematics, which suggest that they correspond to a continuous deformation.

In order to better constrain the internal structure of the accretionary wedge and the temperature difference between the micaschist HP unit and the wedge unit, three samples collected in the wedge unit (KG-14-58, KG-14-64 and KG-14-67) and one sample in the HP unit (KG-11-43) (Figure 9) have been analyzed with Raman spectroscopy of Carbonaceous Material (RSCM). This method is based on the estimation of the degree of organization of the carbonaceous matter (CM) by Raman microspectroscopy (Beyssac et al., 2003, 2002). As this organization is temperature-dependent and persists during retrogression, this method allows determination of the maximum temperature (Tmax) reached by the samples (e.g. Beyssac et al., 2004; Cottle et al., 2011; Rahl et al., 2005). Spectra obtained on samples from the AtBashi complex provide temperatures of $338 \pm 3^{\circ} \mathrm{C}, 537 \pm 7^{\circ} \mathrm{C}$ and $343 \pm 2^{\circ} \mathrm{C}$ for KG-14-58, KG-14-64 and KG-14-67 respectively, and $547 \pm 4^{\circ} \mathrm{C}$ for KG-11-43 (Table 1 and Figure 9). Tmax for the central sample (KG-14-64) of the wedge unit can be explained either by: (i) an antiform structure in the accretionary wedge with deeper, higher grade rocks in the core than on the flanks; (ii) a tectonic mélange within the accretionary wedge where high grade metamorphic slices are mixed with low-grade metamorphic sediments during subduction and subsequent exhumation. In any case, the structure has then been re-folded during the exhumation and collision events.

Finally, the marbles unit overlays the accretionary wedge and micaschist units with a northward kinematics (Figure 9). This allochtonous unit was therefore probably emplaced at the final stage of the collision.

\subsection{The South Tien Shan in Khan-Tengri region}

In the Khan-Tengri area (Figure 11), the STS is mainly composed of Paleozoic metamorphic sedimentary rocks. The oldest formations are of Silurian-Early Devonian age (Zubovich et al., 2008) and consist of light-grey marbles and schists. The Devonian is characterized by metamorphosed sandstones and limestones. The Carboniferous is represented by a succession of thin limestones and dark marls beds. In the Pobeda Massif, a granulitic unit is thrusted over the latter (Loury et al., 2015b).

\subsubsection{New structural observations and cross-section in the Khan-Tengri massif(STS)}

Unlike the At-Bashi massif, the STS in the Khan-Tengri massif does not display typical features of an accretionary complex, but rather corresponds to a nappe stack of several sedimentary units affected by a long wavelength (several $\mathrm{km}$ ) folding possibly of Cenozoic age. The vertical structure of the Khan-Tengri massif can be observed in tectonic windows where Carboniferous and Devonian formations appear overthrusted by Silurian marbles and schists (Figure 11). In the tectonic window of the Khan-Tengri massif, a polyphase ductile deformation with two deformation stages is clearly visible in Carboniferous sediments:

1- A top-to-the-South shearing creates large-scale tight ductile folding of the bedding $S_{0}$ and leads to the development of a north-dipping $S_{1}$ schistosity in the axial plane of the folds (Figures 11, 12a, 12b and 12c).

2- A top-to-the-North shearing reworks the $S_{1}$ schistosity in some places via small-scale folds and creates a south-dipping $S_{2}$ schistosity in the axial planes of $S_{1}$ folds. This $S_{2}$ 
is in turn deformed by an asymmetric top-to-the-North shearing (Figures 11, 13a, 13b and 13c). Lineations indicate a $\sim \mathrm{NNW}-\mathrm{SSW}$ transport direction, i.e. slightly oblique to the normal to schistosity planes.

A non-ambiguous relative chronology can be established due to the overprint of phase (1) by phase (2) as evidenced by the deformation of the top-to-the-South structures by the top-tothe-North deformation phase (Figures 11, 13a, 13b and 13c). Moreover, whereas the $\mathrm{S}_{1^{-}}$related ductile folding is widely distributed and affects the whole sedimentary pile in the Khan Tengri window, the $S_{2}$ deformation is mostly visible near its southern limit where it completely overprints the $S_{1}$. On the contrary, near the northern limit of the window, $S_{2}$ is barely visible (Figure 11, 12c and 13b). Hence, it looks like that the $\mathrm{S}_{2}$ schistosity is more localized than $S_{1}$ and is associated with a major top-to-the-North thrust in the southern part of the Khan-Tengri window.

Two samples (KG-14-18 and KG-14-20) collected in the tectonic window of the KhanTengri massif (Figure 11) have been analyzed with RSCM (Beyssac et al., 2003, 2002). Spectra obtained on these two samples provide temperatures of $587 \pm 9^{\circ} \mathrm{C}$ and $572 \pm 5^{\circ} \mathrm{C}$ for the samples KG-14-18 and KG-14-20 respectively (Table 1) evidencing a peak temperature slightly warmer than that of At-Bashi continental HP metamorphic unit.

Finally, South of the Khan Tengri massif, the granulitic unit of the Pobeda Massif is thrusted along a top-to-the-North shear zone upon Paleozoic formations (South of the Figure 11 frame) (Loury et al., 2015b) but the age (Paleozoic or Cenozoic) of this thrust remains unknown.

\section{Discussion and structural interpretation of the Tien Shan accretionary belt during the Paleozoic.}

\subsection{Paleozoic structures of the Kyrgyz Tien Shan}

\subsubsection{The Song-Kul Zone and the Carboniferous deformation of the North Middle Tien Shan}

Field observations and compilation of bibliographic data in the Song-Kul zone highlighted the presence of both South and North verging thrusts and folds oriented $\sim$ NE-SW. Tectonic and structural analyses provide consistent NW-SE shortening direction and NE-SW stretching direction in both ductile and brittle deformation fields over the whole Song-Kul area. Some NW-SE strike-slip faults appear to act as lateral ramps for the NE-SW thrusts and folds systems. Although its age is poorly constrained, the presence of a NW-SE rhomboidal conglomeratic basin bounded by rectilinear faults in the Toktogul area is compatible with the NE-SW stretching direction. The latter is also visible in a deformed marble unit with a clear stretching lineation. Close to a major EW fault, fold axes and schistosity trend parallel to the direction of the fault. According to the fold and thrust orientations, the orientation of ductile stretching lineation and foliations, we propose that this system worked as a large-scale broad dextral shear zone oriented East-West (Figure 14). This shear zone controlled the regionalscale northward thrusting of the MTS cover over the NTS, but also the southward thrusts and folds in the MTS cover and the local development of NW-SE strike-slip faults and/or pullapart basins in a large flower structure. Along the Song-Kul zone (Figure 2), the most striking feature is the northward thrusting of the MTS Carbonate platform over the NTS detrital and volcanic sequences. Beneath this main thrust, the deformation of the NTS is moderate both in 
the Ordovician substratum and its Carboniferous cover, represented by large wavelength folds and minor thrusts of unknown age (Figure 4).

Chronological relationships between the different units lead us to interpret the thrust and fold structures described above as of Late Carboniferous in age. Indeed, in the Toktogul area, Cenozoic deposits seal a northward thrust in Carboniferous formations (Figure 3). Moreover, Cenozoic formations cropping out inside the mountain range are flat-lying, although uplifted with respect to their basin counterparts. This suggests that Cenozoic shortening is mostly localized on the basin bounding thrusts and that mountain areas have undergone mostly block uplift with only minor internal shortening. The presence of a Late Carboniferous to Early Permian conglomerate sealing the thrusts provides an upper bound for the age of this deformation (i.e., Bashkirian, Bazhenov et al., 2003). The transpressional deformation observed along the northern suture is thus synchronous with the continental collision in the At-Bashi and Khan-Tengri areas; it can therefore be related to the accretion of the Tarim continent against the Kazakh-Yili continental block southward. We thus propose that deformation propagated northward inside the MTS-NTS block up to the Nikolaev line, which was reactivated as a large dextral shear zone. This suggests that the convergence between the Tarim and Kazakh-Yili continents was oblique.

This transpressional deformation developed on the former Ordovician suture between the NTS and the MTS. Although the NTS and the MTS were already accreted during the Carboniferous, they were characterized by different sedimentary conditions, with gypsum and sandstones in the NTS and platform carbonates in the MTS. The Song-Kul zone in the Early Carboniferous was therefore an old continent-shelf transitional domain of the NTS-MTS continent. This broad EW wrench zone that separates the NTS from the MTS, which is the original definition of the Nikolaev line (Nikolaev, 1933), was therefore a crustal-scale structure until at least the middle Carboniferous.

During the Permian, this area was characterized by a dominant strike-slip deformation regime associated with $\sim$ E-W strike-slip faults and by the intrusion of granitic plutons (Alekseev et al., 2009; Biske et al., 2013; Chen et al., 2009; Choulet et al., 2012, 2011; Mikolaichuk et al., 1997; Seltmann et al., 2011; Wang et al., 2009). Whether Permian wrench tectonics took place in the continuity of Carboniferous deformations, or in a completely different setting is difficult to assess. A possible interpretation for the NTS-MTS boundary is that it was activated as a wide strike-slip to transpressional area in the late Carboniferous (with North- and South-verging thrusts) and became a more localized strike-slip zone in the Permian.

\subsubsection{The STS deformation}

In the STS, a major top-to-the-North ductile thrust structure is well marked in the accretionary complex of At-Bashi (Figure 9), particularly in the micaschists unit. To the South, the accretionary complex is uplifted and exhumed along a conjugate south-verging thrust, which separates this unit from the less deformed Devonian-Carboniferous series of the STS-Tarim. In China, similar units and kinematics are found in the same structural position, along the north boundary of the STS (Charvet et al., 2011, 2007). A similar HP accretionary complex is observed north of the Khan-Tengri nappes stack on the Chinese side (e.g. Tian and Wei, 2013). 
The tectonic nappes observed in the Khan-Tengri massif (Figure 11) present temperature range comparable to (or slightly higher than) the highest metamorphic grade units of the STS (Loury et al., 2015b; Simonov et al., 2008; Tagiri et al., 1995; Tian and Wei, 2013). However, the structural position of the Khan-Tengri massif is still unclear and we cannot affirm that these metamorphic sediments are equivalent to the high-grade metamorphic micaschist and gneiss units of At-Bashi. These nappes of Paleozoic sediments are characterized by two superimposed deformation phases where a first top-to-the-South deformation phase is reworked by a second top-to-the-North deformation phase (Figures 11, 12 and 13).

Comparison betwen the Khan-Tengri and At-Bashi regions allow us to propose that the ductile deformation stage characterized by top-to-the-North thrusts corresponds to the same tectonic episode, i.e. to the collision between the Tarim and the Kazakh block. This episode corresponds to the development of the $\mathrm{S}_{2}$ schistosity in both massifs. Oppositely, the origin of the older $S_{1}$ schistosity associated with a top-to-the-South kinematics in the Khan-Tengri area is more difficult to interpret. It can be associated with the exhumation of metamorphic units in the At-Bashi area (evidenced by a top-to-the-South ductile detachment) and correspond to the exhumation of MTS-derived sedimentary units underthrusted beneath the Tarim. The detachment must have then be refolded in the Khan-Tengri area, since it is now a northdipping reverse structure.

Otherwise, the top-to-the-South deformation in the Khan-Tengri massif could be related to the northward burial of this unit beneath the MTS while the already buried At-Bashi HP unit was exhuming (see Beaumont et al., 2009 for details about exhumation processes in collision zones). In this second hypothesis, the top-to-the-South deformation is associated with the underthrusting of the Tarim beneath the MTS. In this case, the At-Bashi and Khan-Tengri units need to be back-thrusted over the MTS in later stage of deformation to reach their final structural position.

This typical collisional deformation sequence has been described similarly in the Chinese TS (Lin et al., 2009; Wang et al., 2010). Numerous thermo-mechanical models of collision zones show continental units that are firstly exhumed along detachment structures and then folded, shortened and thickened during the collision (e.g. Beaumont et al., 2009; Duretz and Gerya, 2013; Z. H. Li et al., 2011; Warren et al., 2008).

Considering the age of sedimentary and magmatic rocks affected or not by this deformation (e.g., Alekseev et al., 2007), we bracket this collisional tectonic event between the Late Carboniferous and the Permian.

Our field data therefore allow us to constrain the collisional event that shaped the STS area at the end of the Paleozoic. However, we cannot bring here decisive arguments in the controversy concerning the vergence of the Carboniferous subduction that preceded collision, because the upper crustal structure is compatible with both senses of subduction. Oppositely, the deep crustal and lithospheric structure should be different depending on the subduction vergence and should influence the Cenozoic deformation in a way that has to be quantified, possibly by thermo-mechanical modelling.

\subsection{Middle Carboniferous NTS/MTS/STS kinematics}

Based on these new field observations we propose a synthetic 3D diagram and kinematic interpretation of the NTS-MTS and MTS-STS sutures during Late Paleozoic (Figure 15). 
During the middle/late Carboniferous collision between the Tarim block and the NTS/MTS continents, the southern suture (At-Bashi) between STS and MTS developed as a rather classical frontal collisional complex, where previously subducted metamorphic rocks were exhumed as different tectonic slices trending parallel to the direction of the range (Figure 15). Oppositely, the MTS/NTS suture was an E-W strike-slip dextral structure with all classically associated deformations (negative and positive flower structures, Figures 14 and 15). These observations suggest that: 1) the collision between the Tarim continent and the Kazakh platform was at least slightly oblique and was accommodated by strain partitioning, with a dip-slip deformation at the colliding plate boundary and a strike-slip deformation further north in the continental plate; 2) the reactivation of the Nikolaev line as a strike-slip zone was favored by a preexisting E-W vertical structuration, otherwise such a strain partitioning would be unlikely. It is therefore possible that the Ordovician accretion of the MTS against the NTS had already occurred in a context of strike-slip setting, similar to today's accretion along the San Andreas Fault (SAF) in the NW America (e.g. Atwater, 1970; Furlong et al., 1989). In this area, oblique convergence between North America and Pacific plates is accommodated by strike-slip faulting along the SAF, which led to the detachment and shortening of a continental block (the Salinian block) against the western North American margin (e.g.Tavarnelli, 1998). This could be a good modern analogue to the MTS/NTS Early Paleozoic tectonics.

Considering very simple plate geometries and kinematics during the Late Carboniferous collisional episode, we can schematically draw the following relative plate kinematics (Figure $15)$ :

- The MTS/STS convergence vector was approximately NNW-SSE (in present coordinates), i.e., perpendicular to the At-Bashi suture, which at the time of the collision belonged to the upper plate (i.e., to the STS-Tarim) according to the north-verging thrusts kinematics. Indeed, whether it was initially a south-dipping or a north-dipping subduction, the STS-Tarim always ends up overthrusting the MTS during the collision stage.

- Meanwhile, the MTS/NTS vector was approximately EW, i.e., parallel to the Nikolaev line. Depending on the relative lengths of both vectors, the relative NTS/STS convergence could have trend approximately NW-SE or WNW-ESE.

- During the collision, this construction can give a stable triple junction located west of the MTS point in the velocity triangle if we assume that the NTS/STS block boundary east of the triple junction was an intraplate oblique convergence zone oriented NE-SW to ENE-WSW. In this case, the NTS/MTS/STS triple junction was migrating fast towards the west, which is consistent with other kinematic reconstructions (Wilhem et al., 2012).

\section{Conclusion}

This study brings new structural data and insights on the timing, nature and extent of Late Paleozoic deformations based on field observations undertaken in the Kyrgyz Middle and South TS. The main phases of deformation are:

- (1) A Middle to Late Carboniferous top-to-the-south deformation phase in the KhanTengri region, possibly coincidental with top-to-the-south detachment on the top of 
the At-Bashi continental unit. This deformation phase can be interpreted as the exhumation of continental-derived units that were previously underthrusted beneath the Tarim.

- (2) A Late Carboniferous top-to-the-North deformation phase, which postdates the top-to-the-south structures in the Khan-Tengri massif. We ascribe this deformation stage to a nappe stack related to the collision between the MTS and the Tarim craton during the Late Carboniferous, based on the age of the pressure peak in At-Bashi HP units and on the age of overlying conglomerates.

- (3) A Late Carboniferous deformation stage characterized by the deformation of the MTS and its thrusting over the NTS. This deformation occurred on a large dextral shear zone between the NTS and the MTS known as Song-Kul Zone or Nikolaev Line and was a "far-field effect" of the Tarim/MTS collision.

\section{Acknowledgments}

This work is part of the first author's PhD thesis granted by the French Ministry of Research. Field studies were supported by the project DSP-Tibet funded by the Agence Nationale de la Recherche (ANR-13-BS06-012-01). Additional support was provided by the Darius programme. Many thanks to Olivier Beyssac and Alberto Vitale-Brovarone (IMPMC, Paris, France) who trained A.J. on the RSCM method. Thanks to Alexander Mikolaichuk (Institute of Geology, National Academy of Science, Bishkek, Kyrgyzstan) for being our guide during this field work. We also thank Editor in chief M. Santosh and Associate Editor Y. Dong for their help, and Michel Faure and three other anonymous reviewers for their constructive remarks. Data presented in this paper are in the figures, tables and the supplement and are available on request at jourdon@geoazur.unice.fr. 


\section{References}

Abdrakhmatov, K., Weldon, R., Thompson, S.C., Burbank, D.W., Rubin, C., Miller, M., Molnar, P., 2001. Onset, style and current rate of shortening in the central Tien Shan, Kyrgyz Republic. Russian Geology and Geophysics 42, 1585-1609.

Abdrakhmatov, K.E., Aldazhanov, S.A., Hager, B.H., Hamburger, M.W., Herring, T.A., Kalabaev, K.B., Makarov, V.I., Molnar, P., Panasyuk, S. V., Prilepin, M.T., Reilinger, R.E., Sadybakasov, I.S., Souter, B.J., Trapeznikov, Y.A., Tsurkov, V.Y., Zubovich, A. V., 1996. Relatively recent construction of the Tien Shan inferred from GPS measurements of present-day crustal deformation rates. Nature 384, 450-453.

Alekseev, D. V., Aristov, V. a., Degtyarev, K.E., 2007. The age and tectonic setting of volcanic and cherty sequences in the ophiolite complex of the Atbashe Ridge (Southern Tien Shan). Doklady Earth Sciences 413, 380-383. doi:10.1134/S1028334X07030130

Alekseev, D. V., Degtyarev, K.E., Kotov, a. B., Sal'nikova, E.B., Tret'yakov, a. a., Yakovleva, S.Z., Anisimova, I. V., Shatagin, K.N., 2009. Late Paleozoic subductional and collisional igneous complexes in the Naryn segment of the Middle Tien Shan (Kyrgyzstan). Doklady Earth Sciences 427, 760-763. doi:10.1134/S1028334X09050122

Allen, M.B., Windley, B.F., Zhang, C., 1993. Palaeozoic collisional tectonics and magmatism of the Chinese Tien Shan, central Asia. Tectonophysics 220, 89-115. doi:10.1016/00401951(93)90225-9

Atwater, T., 1970. Implications of Plate Tectonics for the Cenozoic Tectonic Evolution of Western North America. Geological Society of America Bulletin 81, 3513-3536.

Avouac, J.P., Tapponier, P., Bai, M., You, H., Wang, G., 1993. Active thrusting and folding around the northern Tien Shan and late Cenozoic rotation of the Tarim relative to Dzungaria and Kazakhstan. Journal of Geophysical Research 98, 6755-6804.

Bakirov, A.B., Maksumova, R.A., 2001. Geodynamic evolution of the Tien Shan Litosphere. Russian Geology and Geophysics 42, 1359-1366.

Baslakunov, J., Takasu, A., Tagiri, M., Bakirov, A., Sakiev, K., 2007. Two modes of occurrence of eclogites from the Atbashy Range, southern Tien-Shan, Kyrgyzstan, in: American Geophysical Union Fall Meeting. p. Abstract V41C0730B.

Bazhenov, M.L., Collins, A.Q., Degtyarev, K.E., Levashova, N.M., Mikolaichuk, A. V., Pavlov, V.E., Van der Voo, R., 2003. Paleozoic northward drift of the North Tien Shan (Central Asia) as revealed by Ordovician and Carboniferous paleomagnetism. Tectonophysics 366, 113-141. doi:10.1016/S0040-1951(03)00075-1

Beaumont, C., Jamieson, R. a., Butler, J.P., Warren, C.J., 2009. Crustal structure: A key constraint on the mechanism of ultra-high-pressure rock exhumation. Earth and Planetary Science Letters 287, 116-129. doi:10.1016/j.epsl.2009.08.001

Beyssac, O., Bollinger, L., Avouac, J.P., Goffé, B., 2004. Thermal metamorphism in the lesser Himalaya of Nepal determined from Raman spectroscopy of carbonaceous material. Earth and Planetary Science Letters 225, 233-241. doi:10.1016/j.eps1.2004.05.023

Beyssac, O., Goffé, B., Chopin, C., Rouzaud, J.N., 2002. Raman spectra of carbonaceous material in metasediments: A new geothermometer. Journal of Metamorphic Geology 20, 859-871. doi:10.1046/j.1525-1314.2002.00408.x 
Beyssac, O., Goffé, B., Petitet, J.-P., Froigneux, E., Moreau, M., Rouzaud, J.-N., 2003. On the characterization of disordered and heterogeneous carbonaceous materials by Raman spectroscopy. Spectrochimica Acta Part A: Molecular and Biomolecular Spectroscopy 59, 2267-2276. doi:10.1016/S1386-1425(03)00070-2

Biske, Y.S., 1996. Paleozoic Structure and History of South Tian-Shan (in Russian). SanktPete. St Petersburg.

Biske, Y.S., Konopelko, D.L., Seltmann, R., 2013. Geodynamics of late Paleozoic magmatism in the Tien Shan and its framework. Geotectonics 47, 291-309. doi:10.1134/S001685211304002X

Biske, Y.S., Zubtov, Y.S., Porshnyakov, G.S., 1985. Hercynides of the Atbashi Kokshaal Region Ou the Southern Tian-Shan (in Russian). Leningrad.

Bullen, M.E., Burbank, D.W., Garver, J.I., Abdrakhmatov, K.Y., 2001. Late Cenozoic tectonic evolution of the northwestern Tien Shan: New age estimates for the initiation of mountain building. Geological Society of America Bulletin. doi:10.1130/00167606(2001)113<1544:LCTEOT>2.0.CO;2

Burbank, D.W., McLean, J.K., Bullen, M., Abdrakhmatov, K.Y., Miller, M.M., 1999. Partitioning of intermontane basins by thrust-related folding, Tien Shan, Kyrgyzstan. Basin Research 11, 75-92. doi:10.1046/j.1365-2117.1999.00086.x

Burtman, V.S., 2008. Nappes of the southern Tien Shan. Russian Journal of Earth Sciences 10, 1-35. doi:10.2205/2007ES000223

Buslov, M.M., De Grave, J., Bataleva, E. a V, Batalev, V.Y., 2007. Cenozoic tectonic and geodynamic evolution of the Kyrgyz Tien Shan Mountains: A review of geological, thermochronological and geophysical data. Journal of Asian Earth Sciences 29, 205-214. doi:10.1016/j.jseaes.2006.07.001

Cawood, P.A., Kröner, A., Collins, W.J., Kusky, T.M., Mooney, W.D., Windley, B.F., 2009. Earth Accretionary systems in space and time. Geological Society of London, Special publication 318, 1-36.

Charvet, J., Shu, L.L.S., Laurent-Charvet, S., 2007. Paleozoic structural and geodynamic evolution of eastern Tianshan (NW China): welding of the Tarim and Junggar plates. Episodes 30, 162-172.

Charvet, J., Shu, L.S., Laurent-Charvet, S., Wang, B., Faure, M., Cluzel, D., Chen, Y., de Jong, K., 2011. Palaeozoic tectonic evolution of the Tianshan belt, NW China. Science China Earth Sciences 54, 166-184. doi:10.1007/s11430-010-4138-1

Chen, C., Lu, H., Jia, D., Cai, D., Wu, S., 1999. Closing history of the southern Tianshan oceanic basin, western China: An oblique collisional orogeny. Tectonophysics 302, $23-$ 40. doi:10.1016/S0040-1951(98)00273-X

Chen, H.L., Yang, S.F., Li, Z.L., Yu, X., Luo, J.C., He, G.Y., Lin, X.B., Wang, Q.H., 2009. Spatial and temporal characteristics of Permian large igneous province in Tarim Basin. Xinjiang Pet. Geol. 30, 179-182.

Choulet, F., Chen, Y., Wang, B., Faure, M., Cluzel, D., Charvet, J., Lin, W., Xu, B., 2011. Late Paleozoic paleogeographic reconstruction of Western Central Asia based upon paleomagnetic data and its geodynamic implications. Journal of Asian Earth Sciences 42, 867-884. doi:10.1016/j.jseaes.2010.07.011 
Choulet, F., Faure, M., Cluzel, D., Chen, Y., Lin, W., Wang, B., 2012. From oblique accretion to transpression in the evolution of the Altaid collage: New insights from West Junggar, northwestern China. Gondwana Research 21, 530-547. doi:10.1016/j.gr.2011.07.015

Cottle, J.M., Waters, D.J., Riley, D., Beyssac, O., Jessup, M.J., 2011. Metamorphic history of the South Tibetan Detachment System, Mt. Everest region, revealed by RSCM thermometry and phase equilibria modelling. Journal of Metamorphic Geology 29, 561582. doi:10.1111/j.1525-1314.2011.00930.x

De Boisgrollier, T., Petit, C., Fournier, M., Leturmy, P., Ringenbach, J.C., San'kov, V. a., Anisimova, S. a., Kovalenko, S.N., 2009. Palaeozoic orogeneses around the Siberian craton: Structure and evolution of the Patom belt and foredeep. Tectonics 28. doi:10.1029/2007TC002210

De Grave, J., Buslov, M.M., Van den Haute, P., 2004. Intracontinental deformation in Central Asia : distant effects of India-Eurasia convergence revealed by apatite fission-track thermochronology. Himalayan journal of Sciences 2, 121-122.

Demets, C., Gordon, R.G., Argus, D.F., Stein, S., 1990. Current plate motions 71, 425-478. doi:10.1111/j.1365-246X.1990.tb06579.x

DeMets, C., Gordon, R.G., Argus, D.F., Stein, S., 1994. Effect of recent revisions to the geomagnetic reversal time scale on estimates of current plate motions. Geophysical Research Letters 21, 2191-2194.

Dong, Y., Zhang, G., Neubauer, F., Liu, X., Hauzenberger, C., Zhou, D., Li, W., 2011. Synand post-collisional granitoids in the Central Tianshan orogen: Geochemistry, geochronology and implications for tectonic evolution. Gondwana Research 20, $568-$ 581. doi:10.1016/j.gr.2011.01.013

Dong, Y.P., Zhou, D.W., Zhang, C.L., Xia, L.Q., Xu, X.Y., Li, X.M., 2005. Tectonic setting of the Wuwamen ophiolite at the southern margin of Middle Tianshan Belt. Acta Petrologica Sinica 21, 37-44.

Dong, Y.P., Zhou, D.W., Zhang, G.W., Zhao, X., Luo, J.H., Xu, J.G., 2006. Geology and geochemistry of the Gangou ophiolitic mélange at the northern margin of the Middle Tianshan Belt. Acta Petrologica Sinica 22, 49-56.

Duretz, T., Gerya, T. V., 2013. Slab detachment during continental collision: Influence of crustal rheology and interaction with lithospheric delamination. Tectonophysics 602, 124-140. doi:10.1016/j.tecto.2012.12.024

Faccenda, M., Gerya, T. V., Chakraborty, S., 2008. Styles of post-subduction collisional orogeny: Influence of convergence velocity, crustal rheology and radiogenic heat production. Lithos 103, 257-287. doi:10.1016/j.lithos.2007.09.009

Furlong, K.P., Hugo, W.D., Zandt, G., 1989. Geometry and Evolution of the San Andreas Fault Zone in Northern California. Journal of Geophysical Research 94, 3100-3110.

Gao, J., Li, M., Xiao, X., Tang, Y., He, G., 1998. Paleozoic tectonic evolution of the Tianshan Orogen, northwestern China. Tectonophysics 287, 213-231. doi:10.1016/S00401951(98)80070-X

Gao, J., Long, L., Klemd, R., Qian, Q., Liu, D., Xiong, X., Su, W., Liu, W., Wang, Y., Yang, F., 2009. Tectonic evolution of the South Tianshan orogen and adjacent regions, NW China: Geochemical and age constraints of granitoid rocks. International Journal of Earth Sciences 98, 1221-1238. doi:10.1007/s00531-008-0370-8 
Ge, R., Zhu, W., Wilde, S. a., He, J., Cui, X., Wang, X., Bihai, Z., 2014. Neoproterozoic to Paleozoic long-lived accretionary orogeny in the northern Tarim Craton. Tectonics 33, 302-329. doi:10.1002/2013TC003501

Ge, R., Zhu, W., Wu, H., Zheng, B., Zhu, X., He, J., 2012. The Paleozoic northern margin of the Tarim Craton: Passive or active? Lithos 142-143, 1-15. doi:10.1016/j.lithos.2012.02.010

Glorie, S., De Grave, J., Buslov, M.M., Elburg, M. a., Stockli, D.F., Gerdes, a., Van den haute, P., 2010. Multi-method chronometric constraints on the evolution of the Northern Kyrgyz Tien Shan granitoids (Central Asian Orogenic Belt): From emplacement to exhumation. Journal of Asian Earth Sciences 38, 131-146. doi:10.1016/j.jseaes.2009.12.009

Glorie, S., De Grave, J., Buslov, M.M., Zhimulev, F.I., Stockli, D.F., Batalev, V.Y., Izmer, a., Van Den Haute, P., Vanhaecke, F., Elburg, M. a., 2011. Tectonic history of the Kyrgyz South Tien Shan (Atbashi-Inylchek) suture zone: The role of inherited structures during deformation-propagation. Tectonics 30. doi:10.1029/2011TC002949

Goode, J.K., Burbank, D.W., Bookhagen, B., 2011. Basin width control of faulting in the Naryn Basin, south-central Kyrgyzstan. Tectonics 30, 1-14. doi:10.1029/2011TC002910

Guillot, S., Garzanti, E., Baratoux, D., Marquer, D., Mahéo, G., De Sigoyer, J., 2003. Reconstructing the total shortening history of the NW Himalaya. Geochemistry, Geophysics, Geosystems 4. doi:10.1029/2002GC000484

Guo, J., Shu, L., Charvet, J., Laurent Charvet, S., Sun, S., 2002. Geochemical features of the two early paleozoic ophiolitic zones and volcanic rocks in the central-southern Tianshan Region, Xinjiang. Chinese Journal of Geochemistry 21, 308-321. doi:10.1007/BF02831532

Hegner, E., Klemd, R., Kröner, a., Corsini, M., Alexeiev, D. V., Iaccheri, L.M., Zack, T., Dulski, P., Xia, X., Windley, B.F., 2010. Mineral ages and p-t conditions of late paleozoic high-pressure eclogite and provenance of mélange sediments from atbashi in the south tianshan orogen of kyrgyzstan. American Journal of Science 310, 916-950. doi: $10.2475 / 09.2010 .07$

Isaks, B.L., 1988. Uplift of the Central Andean Plateau and bending of the Bolivian orocline. Journal of Geophysical Research 93, 3211-3231. doi:10.1029/JB093iB04p03211

Jolivet, M., Dominguez, S., Charreau, J., Chen, Y., Li, Y., Wang, Q., 2010. Mesozoic and Cenozoic tectonic history of the central Chinese Tian Shan: Reactivated tectonic structures and active deformation. Tectonics 29. doi:10.1029/2010TC002712

Jong, K. De, Wang, B., Faure, M., Shu, L., Cluzel, D., Charvet, J., Ruffet, G., Chen, Y., 2009. New 40 Ar / 39 Ar age constraints on the Late Palaeozoic tectonic evolution of the western Tianshan ( Xinjiang, northwestern China ), with emphasis on Permian fluid ingress. International Journal of Earth Sciences 98, 1239-1258. doi:10.1007/s00531-0080338-8

Jukov, Y. V., Zakharov, I.L., Berezanskyi, A.V., Izraileva, R.M., 2008. Geological map of the Kyrgyz Republic 1:500 000.

Karpovitch, E.., Kolesnikov, V.A., Lunev, V.P., 1964. Geological map of the former USSR, 1:200 000 sheets. Alay-Kokshaal series K-43-XXVIII.

Keselev, V.V., Zhukov, Y.V., Israileva, R.M., Komarevstev, V.T., Tsyganok, E.N., 1982. 
Radiological Evidence for the Grenville Tectono-Magmatic Stage in the Northern Tianshan. Izvestiya Academy of Sciences of the Kyrgyz SSR 6, 26-30 (in Russian).

Kiselev, V. V., Apayarov, F.K., Komartsev, V.T., Tsyganok, E.N., Lukashova, E.M., 1993. Isotopic ages of zircons from crystalline complexes of the Tianshan, in: Kozakov, I.K. (Ed.), Early Precambrian of the Central Asia Folded Belt. St. Petersbourg, pp. 99-115.

Konopelko, D., Biske, G., Seltmann, R., Kiseleva, M., Matukov, D., Sergeev, S., 2008.

Deciphering Caledonian events: Timing and geochemistry of the Caledonian magmatic arc in the Kyrgyz Tien Shan. Journal of Asian Earth Sciences 32, 131-141. doi:10.1016/j.jseaes.2007.10.017

Konopelko, D., Seltmann, R., Apayarov, F., Belousova, E., Izokh, a., Lepekhina, E., 2013. U$\mathrm{Pb}$-Hf zircon study of two mylonitic granite complexes in the Talas-Fergana fault zone, Kyrgyzstan, and Ar-Ar age of deformations along the fault. Journal of Asian Earth Sciences 73, 334-346. doi:10.1016/j.jseaes.2013.04.046

Kröner, a., Alexeiev, D. V., Hegner, E., Rojas-Agramonte, Y., Corsini, M., Chao, Y., Wong, J., Windley, B.F., Liu, D., Tretyakov, a. a., 2012. Zircon and muscovite ages, geochemistry, and Nd-Hf isotopes for the Aktyuz metamorphic terrane: Evidence for an Early Ordovician collisional belt in the northern Tianshan of Kyrgyzstan. Gondwana Research 21, 901-927. doi:10.1016/j.gr.2011.05.010

Kröner, a., Alexeiev, D. V., Rojas-Agramonte, Y., Hegner, E., Wong, J., Xia, X., Belousova, E., Mikolaichuk, a. V., Seltmann, R., Liu, D., Kiselev, V. V., 2013. Mesoproterozoic (Grenville-age) terranes in the Kyrgyz North Tianshan: Zircon ages and Nd-Hf isotopic constraints on the origin and evolution of basement blocks in the southern Central Asian Orogen. Gondwana Research 23, 272-295. doi:10.1016/j.gr.2012.05.004

Kröner, a., Kovach, V., Belousova, E., Hegner, E., Armstrong, R., Dolgopolova, a., Seltmann, R., Alexeiev, D. V., Hoffmann, J.E., Wong, J., Sun, M., Cai, K., Wang, T., Tong, Y., Wilde, S. a., Degtyarev, K.E., Rytsk, E., 2014. Reassessment of continental growth during the accretionary history of the Central Asian Orogenic Belt. Gondwana Research 25, 103-125. doi:10.1016/j.gr.2012.12.023

Kusky, T.M., 2011. Geophysical and geological tests of tectonic models of the North China Craton. Gondwana Research 20, 26-35. doi:10.1016/j.gr.2011.01.004

Lasovski, A.G., Mozolev, N., 1960. Geological map of the former USSR, 1:200 000 sheets. North-Tien-Shan series, K-43-XXII.

Laurent-Charvet, S., 2001. Accrétions continentales en Asie évolution géodynamique et structurale du Tianshan et du Junggar oriental ( nord-ouest Chine ) au Paléozoïque. Université d'Orléans, France.

Laurent-Charvet, S., Charvet, J., Monié, P., Shu, L., 2003. Late Paleozoic strike-slip shear zones in eastern central Asia (NW China): New structural and geochronological data. Tectonics 22, 1009. doi:10.1029/2001TC901047

Laurent-Charvet, S., Charvet, J., Shu, L., Ma, R., Lu, H., 2002. Palaeozoic late collisional strike-slip deformations in Tianshan and Altay, Eastern Xinjiang, NW China. Terra Nova 14, 249-256. doi:10.1046/j.1365-3121.2002.00417.x

Le Fort, P., 1975. Himalayas: the collided range. Present knowledge of the continental arc. American Journal of Science 275, 44.

Lei, R.X., Wu, C.Z., Gu, L.X., Zhang, Z.Z., Chi, G.X., Jiang, Y.H., 2011. Zircon u-pb 
chronology and hf isotope of the xingxingxia granodiorite from the central tianshan zone (nw china): Implications for the tectonic evolution of the southern altaids. Gondwana Research 20, 582-593. doi:10.1016/j.gr.2011.02.010

Li, Q.L., Lin, W., Su, W., Li, X.H., Shi, Y.H., Liu, Y., Tang, G.Q., 2011. SIMS U-Pb rutile age of low-temperature eclogites from southwestern Chinese Tianshan, NW China. Lithos 122, 76-86. doi:10.1016/j.lithos.2010.11.007

Li, Z.H., Xu, Z.Q., Gerya, T. V., 2011. Flat versus steep subduction: Contrasting modes for the formation and exhumation of high- to ultrahigh-pressure rocks in continental collision zones. Earth and Planetary Science Letters 301, 65-77. doi:10.1016/j.epsl.2010.10.014

Lin, W., Chu, Y., Ji, W.B., Zhang, Z.P., Shi, Y.H., Wang, Z.Y., Li, Z., Wang, Q.C., 2013. Geochronological and geochemical constraints for a middle Paleozoic continental arc on the northern margin of the Tarim block: Implications for the Paleozoic tectonic evolution of the South Chinese Tianshan. Lithosphere 5, 355-381.

Lin, W., Faure, M., Shi, Y., Wang, Q., Li, Z., 2009. Palaeozoic tectonics of the south-western Chinese Tianshan: New insights from a structural study of the high-pressure/lowtemperature metamorphic belt. International Journal of Earth Sciences 98, 1259-1274. doi:10.1007/s00531-008-0371-7

Liu, X., Su, W., Gao, J., Li, J., Jiang, T., Zhang, X., Ge, X., 2014. Lithos Paleozoic subduction erosion involving accretionary wedge sediments in the South Tianshan Orogen : Evidence from geochronological and geochemical studies on eclogites and their host metasediments. LITHOS 210-211, 89-110. doi:10.1016/j.lithos.2014.09.017

Lomize, M.G., Demina, L.I., Zarshchicov, A.V., 1997. The Kyrgyz-Terskei paleoceanic basin in the Tien Shan. Geotectonics (in Russian with english abstract) 30, 463-482.

Loury, C., Rolland, Y., Cenki-Tok, B., Lanari, P., Guillot, S., 2015a. Late Paleozoic evolution of the South Tien Shan : Insights from P-T estimates and allanite geochronology on retrogressed eclogites. Journal of Geodynamics. doi:10.1016/j.jog.2015.06.005

Loury, C., Rolland, Y., Guillot, S., Mikolaichuk, A. V, Lanari, P., Bruguier, O., Bosch, D., 2015b. Crustal-scale structure of South Tien Shan : implications for subduction polarity and Cenozoic reactivation. Geological Society of London, Special publication 427. doi: $10.1144 /$ SP427.4

Ma, R., Wang, C., Ye, S., 1993. Tectonic framework and crustal evolutional of Eastern Tianshan mountains. Publishing House of Nanjing University, Nanjing 1-225 (in Chinese with english abstract).

Macaulay, E. a., Sobel, E.R., Mikolaichuk, A., Kohn, B., Stuart, F.M., 2014. Cenozoic deformation and exhumation history of the Central Kyrgyz Tien Shan. Tectonics 33, 135-165. doi:10.1002/2013TC003376

Macaulay, E. a., Sobel, E.R., Mikolaichuk, A., Landgraf, A., Kohn, B., Stuart, F., 2013. Thermochronologic insight into late Cenozoic deformation in the basement-cored Terskey Range, Kyrgyz Tien Shan. Tectonics 32, 487-500. doi:10.1002/tect.20040

Mikolaichuk, A., Kurenkov, K.E., Degtyarev, V., Rubetsov, V.I., 1997. Northern Tien Shan main stages of geodynamic evolution in the Late-Precambrian-Early Paleozoic. Geodynamics 6, 16-34.

Nikolaev, V.A., 1933. About principal structure line of Tianshan. Proceedings of All-Russian 
Mineralogical Society 62, 347-354 (in Russian).

Osmonbetov, K.O., Knauf, V.I., Korolev, V.G., 1982. Stratified and intrusive formations of Kyrgyzstan, Illim Pres. ed. Frunze.

Patriat, P., Achache, J., 1984. India-Eurasia collision chronology has implications for crustal shortening and driving mechanisms of plates. Nature 311, 615-621.

Qian, Q., Gao, J., Klemd, R., He, G., Song, B., Liu, D., Xu, R., 2009. Early Paleozoic tectonic evolution of the Chinese South Tianshan Orogen: Constraints from SHRIMP zircon U$\mathrm{Pb}$ geochronology and geochemistry of basaltic and dioritic rocks from Xiate, NW China. International Journal of Earth Sciences 98, 551-569. doi:10.1007/s00531-0070268-x

Rahl, J.M., Anderson, K.M., Brandon, M.T., Fassoulas, C., 2005. Raman spectroscopic carbonaceous material thermometry of low-grade metamorphic rocks: Calibration and application to tectonic exhumation in Crete, Greece. Earth and Planetary Science Letters 240, 339-354. doi:10.1016/j.eps1.2005.09.055

Rolland, Y., Alexeiev, D. V., Kröner, A., Corsini, M., Loury, C., Monié, P., 2013. Late Palaeozoic to Mesozoic kinematic history of the Talas-Ferghana strike-slip fault (Kyrgyz West Tianshan) as revealed by 40Ar/39Ar dating of syn-kinematic white mica. Journal of Asian Earth Sciences 67-68, 76-92. doi:10.1016/j.jseaes.2013.02.012

Rolland, Y., Perincek, D., Kaymakci, N., Sosson, M., Barrier, E., Avagyan, A., 2012. Evidence for $\sim 80-75 \mathrm{Ma}$ subduction jump during Anatolide-Tauride-Armenian block accretion and $\sim 48 \mathrm{Ma}$ Arabia-Eurasia collision in Lesser Caucasus-East Anatolia. Journal of Geodynamics 56-57, 76-85. doi:10.1016/j.jog.2011.08.006

Seltmann, R., Konopelko, D., Biske, G., Divaev, F., Sergeev, S., 2011. Hercynian postcollisional magmatism in the context of Paleozoic magmatic evolution of the Tien Shan orogenic belt. Journal of Asian Earth Sciences 42, 821-838. doi:10.1016/j.jseaes.2010.08.016

Şengör, a. M.C., Natal'in, B. a., Burtman, V.S., 1993. Evolution of the Altaid tectonic collage and Palaeozoic crustal growth in Eurasia. Nature 364, 299-307. doi:10.1038/364299a0

Simonov, V. a., Sakiev, K.S., Volkova, N.I., Stupakov, S.I., Travin, a. V., 2008. Conditions of formation of the Atbashi Ridge eclogites (South Tien Shan). Russian Geology and Geophysics 49, 803-815. doi:10.1016/j.rgg.2008.04.001

Sobel, E.R., Chen, J., Heermance, R. V., 2006. Late Oligocene-Early Miocene initiation of shortening in the Southwestern Chinese Tian Shan: Implications for Neogene shortening rate variations. Earth and Planetary Science Letters 247, 70-81.

Sobel, E.R., Dumitru, T.A., 1997. Exhumation of the margins of the western Tarim basin during the Himalayan orogeny. Journal of Geophysical Research 102, 5043-5064.

Su, W., Gao, J., Klemd, R., Li, J.-L., Zhang, X., Li, X.-H., Chen, N.-S., Zhang, L., 2010. U$\mathrm{Pb}$ zircon geochronology of Tianshan eclogites in NW China: implication for the collision between the Yili and Tarim blocks of the southwestern Altaids. European Journal of Mineralogy 22, 473-478. doi:10.1127/0935-1221/2010/0022-2040

Tagiri, M., Yano, T., Bakirov, A., Nakajima, T., Uchiumi, S., 1995. Mineral parageneses and metamorphic P-T paths of ultrahigh-pressure eclogites from Kyrghyzstan Tien-Shan. The Island Arc 4, 280-292. 
Tapponnier, P., Peltzer, G., Armijo, R., 1986. On the mechanics of the collision between India and Asia. Geological Society of London, Special publication 19, 115-157.

Tavarnelli, E., 1998. Tectonic evolution of the Northern Salinian Block, California, USA: Paleogene to Recent shortening in a transform fault-bounded continental fragment. Geological Society of London, Special publication 35, 107-118. doi:10/1144/GSL.SP.1998.135.01.07

Thompson, S.C., Weldon, R.J., Rubin, C.M., Abdrakhmatov, K., Molnar, P., Berger, G.W., 2002. Late Quaternary slip rates across the central Tien Shan, Kyrgyzstan, Central Asia. Journal of Geophysical Research 107, 2203. doi:10.1029/2001LB000596

Tian, Z.L., Wei, C.J., 2013. Metamorphism of ultrahigh-pressure eclogites from the Kebuerte Valley, South Tianshan, NW China: Phase equilibria and P-T path. Journal of Metamorphic Geology 31, 281-300. doi:10.1111/jmg.12021

Vanderhaeghe, O., 2012. The thermal-mechanical evolution of crustal orogenic belts at convergent plate boundaries: A reappraisal of the orogenic cycle. Journal of Geodynamics 56-57, 124-145. doi:10.1016/j.jog.2011.10.004

Wang, B., Chen, Y., Zhan, S., Shu, L., Faure, M., Cluzel, D., Charvet, J., Laurent-charvet, S., 2007a. Primary Carboniferous and Permian paleomagnetic results from the Yili Block ( NW China ) and their implications on the geodynamic evolution of Chinese Tianshan Belt. Earth and Planetary Science Letters 263, 288-308. doi:10.1016/j.epsl.2007.08.037

Wang, B., Cluzel, D., Shu, L., Faure, M., Charvet, J., Chen, Y., Meffre, S., de Jong, K., 2009. Evolution of calc-alkaline to alkaline magmatism through Carboniferous convergence to Permian transcurrent tectonics, western Chinese Tianshan. International Journal of Earth Sciences 98, 1275-1298. doi:10.1007/s00531-008-0408-y

Wang, B., Faure, M., Shu, L., Cluzel, D., Charvet, J., De Jong, K., Chen, Y., 2008. Paleozoic tectonic evolution of the Yili Block, western Chinese Tianshan. Bulletin de la Societe Geologique de France 179, 483-490. doi:10.2113/gssgfbull.179.5.483

Wang, B., Faure, M., Shu, L., Jong, K. De, Charvet, J., Cluzel, D., Jahn, B., Chen, Y., Ruffet, G., The, S., January, N., Wang, B., Faure, M., Shu, L., Jong, K. De, Charvet, J., Cluzel, D., Jahn, B., Chen, Y., Ruffet, G., 2010. Structural and Geochronological Study of High - Pressure Metamorphic Rocks in the Kekesu Section ( Northwestern China ): Implications for the Late Paleozoic Tectonics of the Southern Tianshan Structural and Geochronological Study of High-Pressure Metamorp. Journal of Geology 118, 59-77. doi:10.1086/648531

Wang, B., Shu, L., Faure, M., Jahn, B.M., Cluzel, D., Charvet, J., Chung, S.L., Meffre, S., 2011. Paleozoic tectonics of the southern Chinese Tianshan: Insights from structural, chronological and geochemical studies of the Heiyingshan ophiolitic mélange (NW China). Tectonophysics 497, 85-104. doi:10.1016/j.tecto.2010.11.004

Wang, B., Shu, L.S., Cluzel, D., Faure, M., Charvet, J., 2007b. Geochemical constraints on Carboniferous volcanic rocks of the Yili Block (Xinjiang, NW China): Implication for the tectonic evolution of Western Tianshan. Journal of Asian Earth Sciences 29, 148159. doi:10.1016/j.jseaes.2006.02.008

Wang, B., Zhai, Y., Shu, L., Liu, H., 2016. Diachronous evolution of back-arc oceanic basins in the South Chinese Tianshan : insights for Paleozoic accretionary tectonics of SW Central Asian Orogenic Belt. The Geological Society of America Bulletin. 
Warren, C.J., Beaumont, C., Jamieson, R. a., 2008. Modelling tectonic styles and ultra-high pressure (UHP) rock exhumation during the transition from oceanic subduction to continental collision. Earth and Planetary Science Letters 267, 129-145. doi:10.1016/j.epsl.2007.11.025

Wilhem, C., Windley, B.F., Stampfli, G.M., 2012. The Altaids of Central Asia: A tectonic and evolutionary innovative review. Earth-Science Reviews 113, 303-341. doi:10.1016/j.earscirev.2012.04.001

Windley, B.F., Alexeiev, D.V., Xiao, W., Kröner, A., Badarch, G., 2007. Tectonic models for accretion of the Central Asian Orogenic Belt. Journal of the Geological Society, London 164, 31-47. doi:10.1144/0016-76492006-022

Windley, B.F., Allen, M.B., Zhang, C., Zhao, Z.Y., Wang, G.R., 1990. Paleozoic accretion and Cenozoic redeformation of the Chinese Tien Shan Range, central Asia. Geology 18, 128-131. doi:10.1130/0091-7613(1990)018<0128:PAACRO>2.3.CO;2

Xiao, W., Han, C., Liu, W., Wan, B., Zhang, J., Ao, S., Zhang, Z., Song, D., Tian, Z., Luo, J., 2014. How many sutures in the southern Central Asian Orogenic Belt: Insights from East Xinjiang-West Gansu (NW China)? Geoscience Frontiers 5, 525-536. doi:10.1016/j.gsf.2014.04.002

Xiao, W., Windley, B.F., Allen, M.B., Han, C., 2013. Paleozoic multiple accretionary and collisional tectonics of the Chinese Tianshan orogenic collage. Gondwana Research 23, 1316-1341. doi:10.1016/j.gr.2012.01.012

Xiao, W., Windley, B.F., Badarch, G., Sun, S., Li, J., Qin, K., Wang, Z., 2004. Paleozoic accretionary and convergent tectonics of the southern Altaids: implications for the growth of Central Asia. Journal of the Geological Society, London 161, 339-342.

Yang, S., Li, Z., Chen, H., Santosh, M., Dong, C., Yu, X., 2007. Permian bimodal dyke of Tarim Basin , NW China : Geochemical characteristics and tectonic implications. Gondwana Research 12, 113-120. doi:10.1016/j.gr.2006.10.018

Yarmolyuk, V.V., Kuzmin, M.I., Ernst, R.E., 2014. Intraplate geodynamics and magmatism in the evolution of the Central Asian Orogenic Belt. Journal of Asian Earth Sciences 93, $158-179$.

Yin, A., Craig, P., Harrison, T.M., Ryerson, F.J., Qian, X., Yang, G., 1998. Late Cenozoic tectonic evolution of the southern Chinese Tian Shan. Tectonics 17, 1-27.

Zhang, L.F., Du, J.X., Shen, X.J., Lü, Z., Song, S.G., Wei, C.J., 2009. The timing of UHP-HP eclogitic rocks in Western Tianshan, NW China: the new SIMS U-Pb zircon dating, $\mathrm{Lu} / \mathrm{Hf}$ and $\mathrm{Sm} / \mathrm{Nd}$ isochron ages, in: 8th International Eclogite Conference.

Zhong, L., Wang, B., Shu, L., Liu, H., Mu, L., Ma, Y., Zhai, Y., 2014. Structural overprints of early Paleozoic arc-related intrusive rocks in the Chinese Central Tianshan : implications for Paleozoic accretionary tectonics in SW Central Asian Orogenic Belts State Key Laboratory for Mineral Deposits Research, School of Eart. Journal of Asian Earth Sciences. doi:10.1016/j.jseaes.2014.12.003

Zhu, Y., Zhang, L., Gu, L., Guo, X., Zhou, J., 2005. The zircon SHRIMP chronology and trace element geochemistry of the Carboniferous volcanic rocks in western Tianshan Mountains. Chinese Science Bulletin 50, 2201-2212. doi:10.1007/BF03182672

Zubovich, A. V., Bobrovski, A., Mikolaichuk, A., Buchroithner, M.F., 2008. Quaternary removed geological map of the Khan Tengri Massif, 1:200 000. Kyrgyz-Russian Slavic 
university, International Science \& Technology Center.

\section{Figure Captions}

Figure 1: Synthetic structural map of the CAOB and surrounding areas from Kyrgyzstan to North China. (Modified after (Charvet et al., 2011; Xiao et al., 2013) and official 1:500 000 geological map of Kyrgyz Republic). 1. Talas Fergana Fault; 2. Nikolaev Line (reworking the Terskey suture); 3. At-Bashi-Inylshek Fault (reworking the Turkestan Ocean suture); 4.Narat Fault; 5. North Tien Shan Fault; 6. Baluntai Fault; 7. Main Tien Shan Shear Zone; 8. North Tarim Fault. Insets show the location of Figures 2, 9 and 11.

Figure 2: Geological and structural map of the Song Kul Zone (modified after Jukov et al., 2008; Karpovitch et al., 1964; Lasovski and Mozolev, 1960; see location on Figure 1). Insets show the location of figures 3, 4, 6 and 8. Lower panel shows synthetic stratigraphic logs of the NTS and MTS respectively.

Figure 3: Geological map and cross-section of the Toktogul reservoir area (see Figure 2 for location). The cross-section is indicated on the map by the thick black line. Star indicates the location of the picture.

Figure 4: Geological map and cross-section of the Central Song-Kul area (see Figure 2 for location). The cross-section is indicated on the map by the thick black line. The stars indicate the locations of field pictures on Figure 5.

Figure 5: Field pictures and their interpretations of the Central Song Kul area. a. Northward thrusting of Ordovician Rhyolites on Cenozoic sediments; b. Northward overturned anticline with Cenozoic sediments overlying Jurassic gypsum-bearing deposits; c. Unconformity between Ordovician rhyolites and Carboniferous (Serpukhovian) gypsum-bearing sandstones typical of the NTS domain; d. Small-scale internal thrust in Carboniferous (Serpukhovian) gypsum-bearing sandstones. See Figure 4 for location.

Figure 6: Geological map and cross-section south of the Song Kul Lake. The thick black line indicates the cross-section location. The stars indicate the location of field pictures shown on Figure 7. The stereoplot shows the projection, in the Schmidt diagram lower hemisphere, of the bedding, schistosity, lineation and faults measured in this zone. The thicker black line on the cross-section indicates a ductile detachment.

Figure 7: Field pictures and their interpretations of the Lake Song Kul area. a. Normal fault in Carboniferous platform carbonates (Tournaisian) of the MTS; b. Deformed marbles with asymmetric top to the SW ductile shearing; c. Top to the North thrusting of the marbles on Tournaisian MTS carbonate platform and Devonian sediments; d. Southward overturned folds in Visean pelites and sandstones. Figure 6 displays the location of pictures.

Figure 8: Geological map and cross-section of the East Son-Kul area. The thick black line indicates the cross-section location. Star indicates the picture location. The stereoplot shows the projection, in Schmidt diagram lower hemisphere, of the schistosity measured in this zone. The picture shows the vertical dextral fault considered as the trace of the Nikolaev Line at the surface. 
Figure 9: Geological map and cross-section of the At-Bashi area modified after (Karpovitch et al., 1964). The thick black line indicates the cross-section location. The stars indicate the location of Figure 10 pictures. Red dots on the cross-section indicate the location of the samples KG-14-58, KG-14-64 and KG-14-67 (from North to South). The stereoplot shows the projection, in the Schmidt diagram lower hemisphere, of the $S_{1}$ (blue lines), $S_{2}$ (green lines) schistosity, lineations (solid dots) and fold axis (orange dots) measured in this zone.

Figure 10: Field pictures and their interpretations of the At-Bashi accretionary complex. a. Top-to-the north asymmetric shearing in the micaschist unit. b. Accretionary wedge with metabasite boudins. The $\mathrm{S}_{0}-\mathrm{S}_{1}$ is folded and a $\mathrm{S}_{2}$ schistosity is developed in the axial fold planes. c. Metabasite boudin metamorphosed in the blueschists facies. d. Northward thrusting of marble units onto the accretionary wedge. See Figure 9 for the location of pictures.

Figure 11: Geological and structural map (Modified after (Zubovich et al., 2008)) and crosssection of eastern Kyrgyz Middle and South Tien Shan in the Khan-Tengri region. NL: Nikolaev Line. AIF: At-Bashi-Inylchek Fault. The thick black line indicates the cross-section location. The stars indicate the location of field pictures shown on Figures 12 and 13. The red dots on the cross-section indicate the location of the samples KG-14-18 and KG-14-20 (from North to South). 1. Top-to-the south deformation. 2. Top-to-the north deformation. A, B and $\mathrm{C}$ represent detailed structures visible along the N-S cross-section (See pictures on figures 12 and 13). The stereoplot shows the projection, in the Schmidt diagram lower hemisphere, of the $S_{1}$ (blue lines), $S_{2}$ (green lines) schistosity, lineations (solid dots) and fold axis (orange dots) measured in this zone.

Figure 12: Field pictures and their interpretations in the Khan-Tengri tectonic window. a. Development of the $S_{1}$ schistosity in the axial fold planes of the $S_{0}$. b. Top-to-the-South shearing of the $S_{1}$ schistosity. c. Large-scale southward overturned ductile folds in the STS meta-sediments. See Figure 11 for the location of pictures.

Figure 13: Field pictures and their interpretations in the Khan-Tengri tectonic window. a. Development of the $S_{2}$ schistosity in the axial folds planes of the $S_{1}$ schistosity and its top-tothe-North shearing. b. Large scale southward overturned folds of the $S_{0}$ associated with the development of the $S_{1}$ schistosity in the axial fold planes of the $S_{0}$ and top to the south shearing. The $S_{1}$ schistosity is then folded and associated with the development of the $S_{2}$ schistosity in the axial fold planes of $S_{1}$ and top to the North shearing. The blow-up shows the development of the $S_{2}$ in the axial fold planes of the $S_{1}$. c. Top to the North shearing of the $S 2$ schistosity. See Figure 11 for the location of pictures.

Figure 14: 3D interpretative structural diagram of the dextral shear zone of the Song-Kul Zone showing the lateral (from West to East) correlation of the structures associated with the strike-slip shear zone during Late Carboniferous times. Stereoplots represent stratigraphic (black lines), schistosity (blue lines) and faults (red lines) planes measured in the Song Kul Zone and projected in the Schmidt projection lower hemisphere.

Figure 15: Structural and kinematic scheme of the Middle-Late Carboniferous oblique collision between the Tarim and the Kazakh platform, with a strain partitioning between a frontal collision to the south and a strike-slip motion to the North. Inset shows possible schematic block boundaries geometry (left) with mean strain directions compatible with field observations, and velocity triangle (right, no scale); plate boundaries are delineated with different colors. $\mathrm{P}$ is the Tarim-NTS-MTS triple junction. 
Table 1: Selected samples for RSCM thermometry. The name and the nature of the samples are indicated in the Sample and Rock column respectively. The GPS positions of the samples are given in decimal degrees (WGS84). $\mathrm{n}$ Indicates the number of spectra used to calculate the mean R2 ratio after (Beyssac et al., 2002) with corresponding standard deviation (SD) and calculated Temperature (Tmax) with standard error (SE). Standard error is standard deviation divided by $\sqrt{n}_{\mathrm{n}}$. The absolute error on temperature is $\pm 50^{\circ} \mathrm{C}$ (Beyssac et al., 2002). 


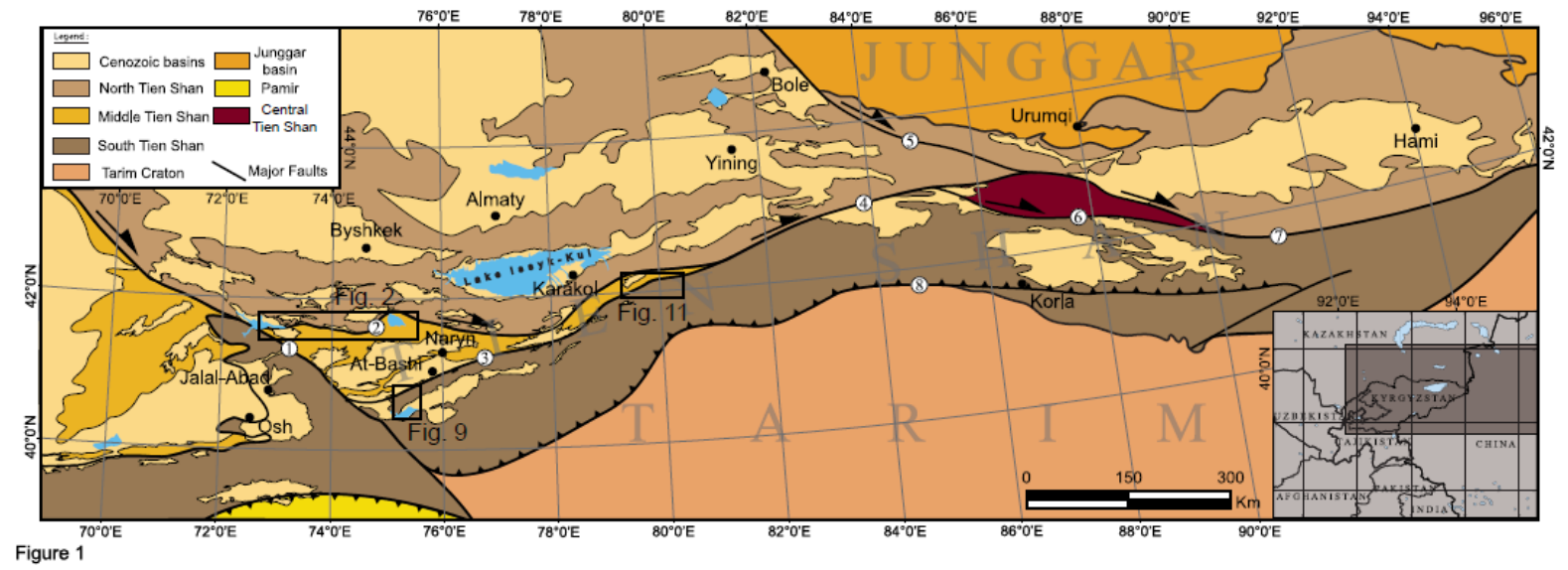

Fig. 1 


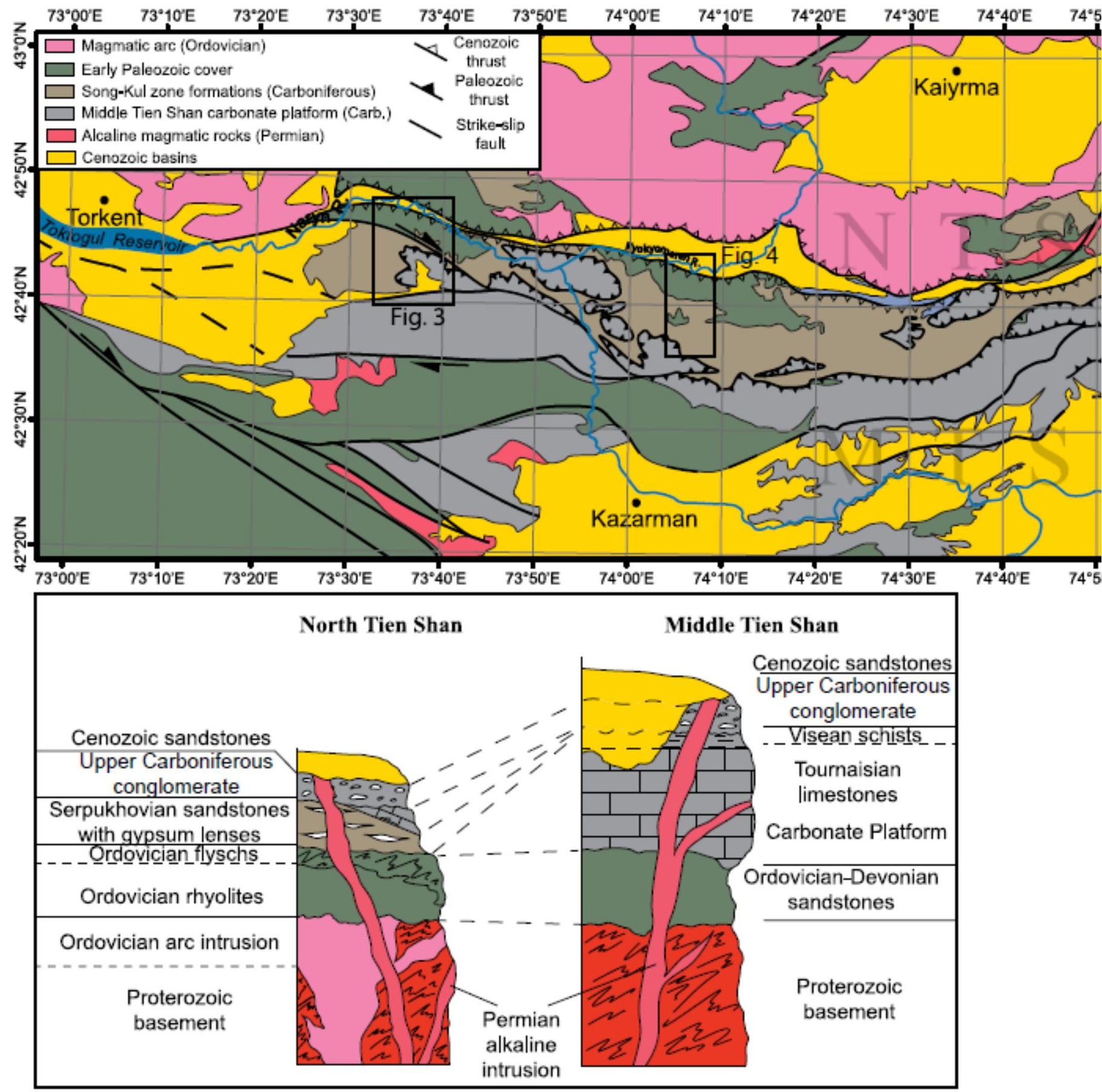

Fig. 2 

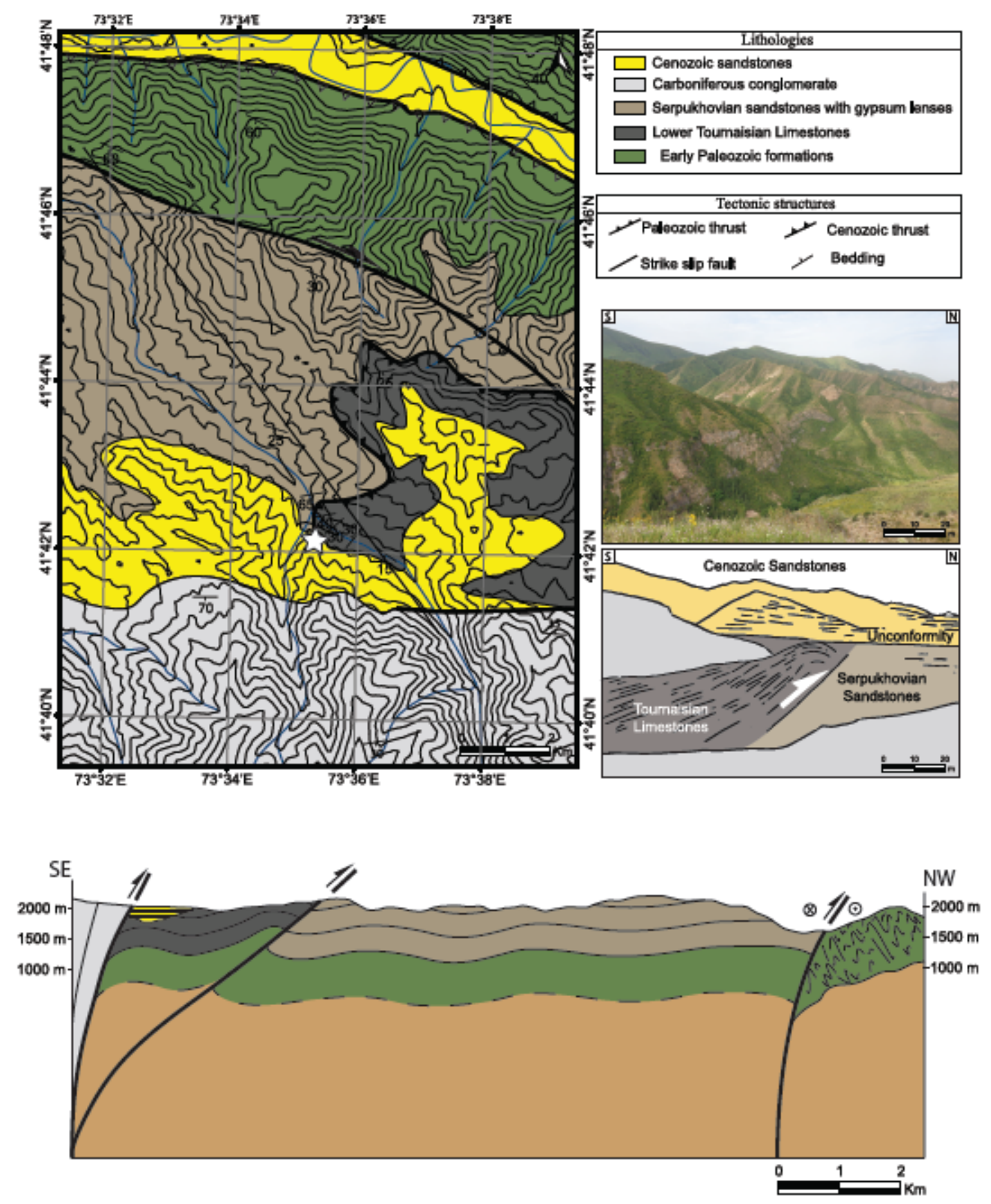

Fig 3 

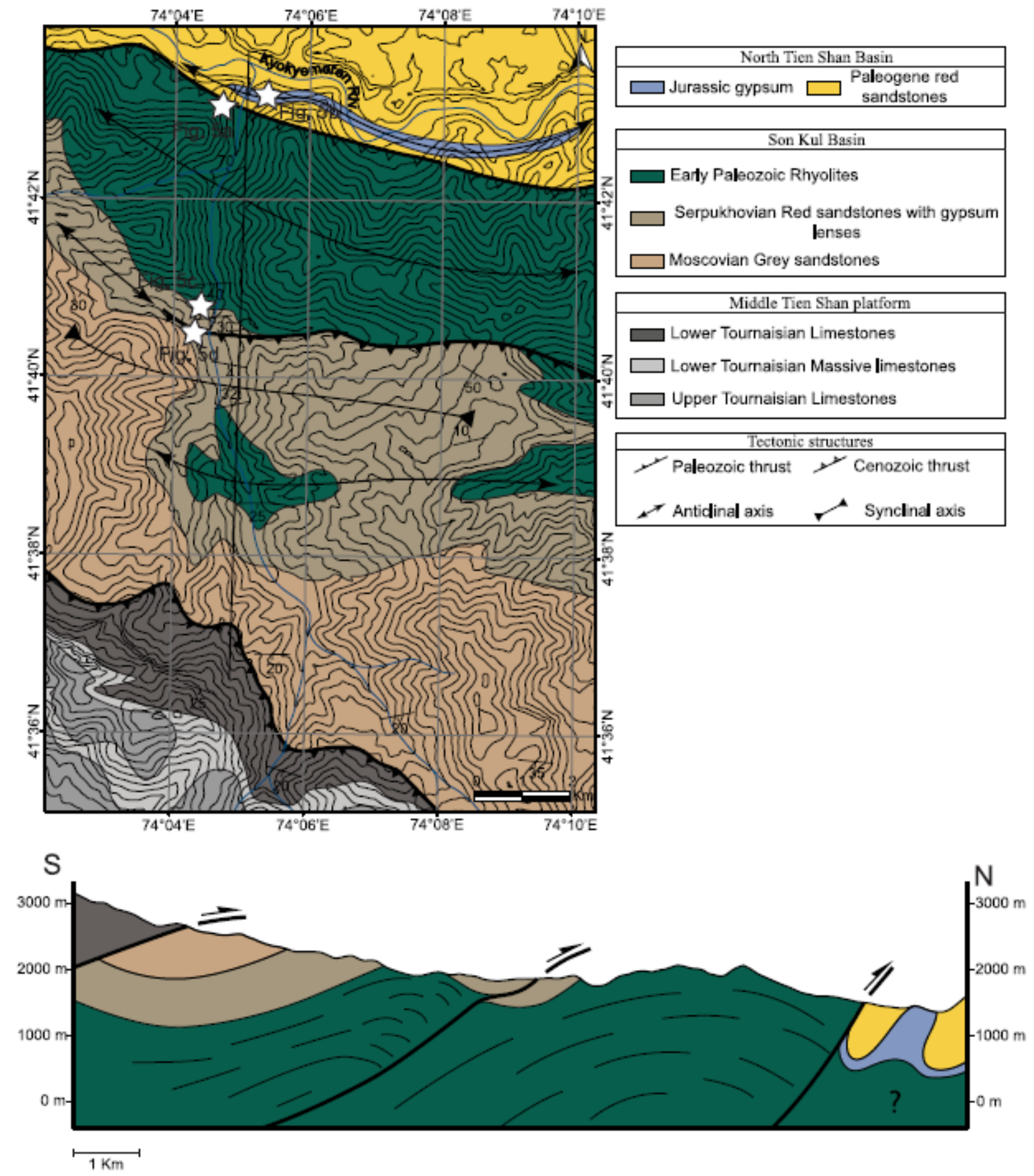

Fig 4 

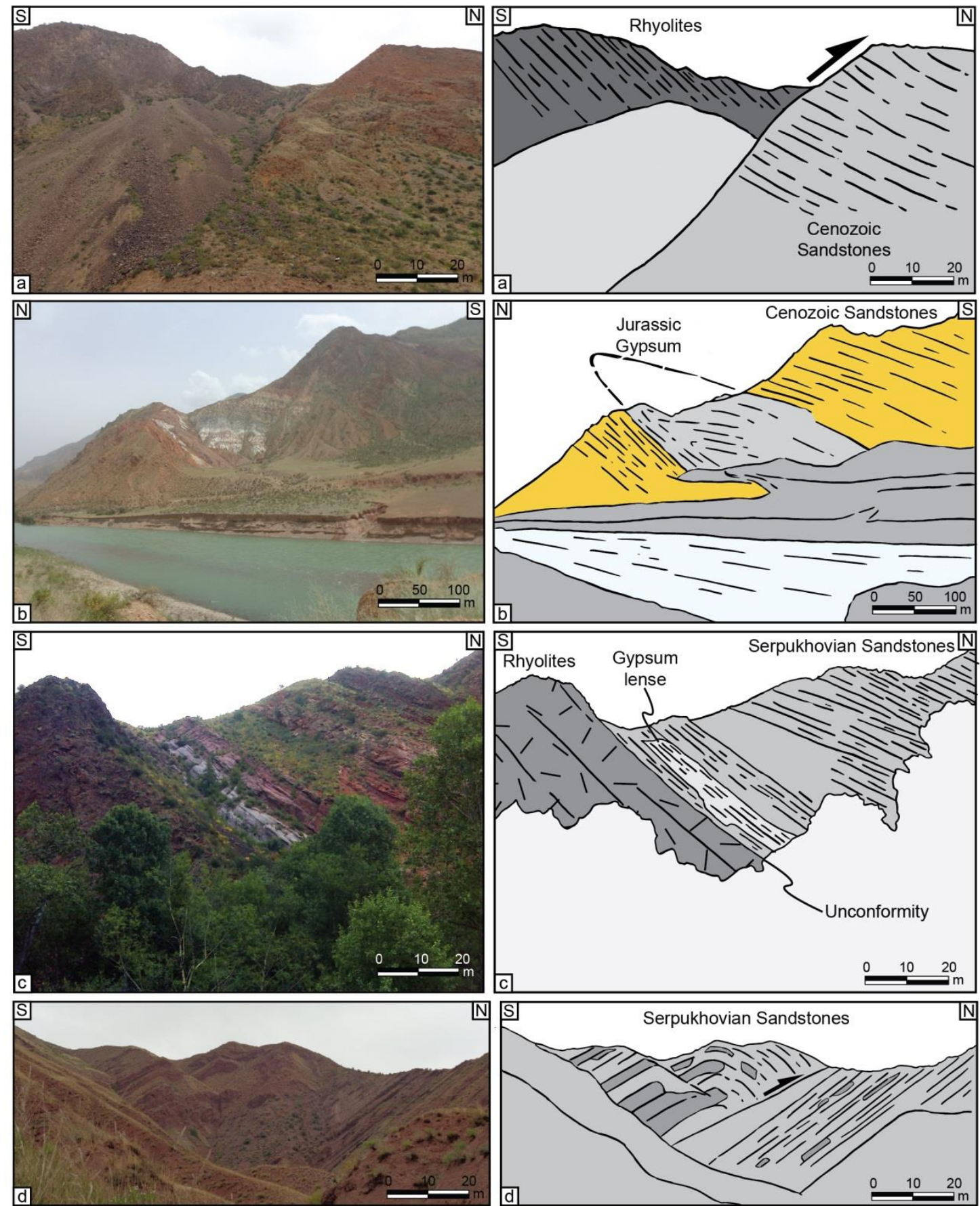

Fig. 5 

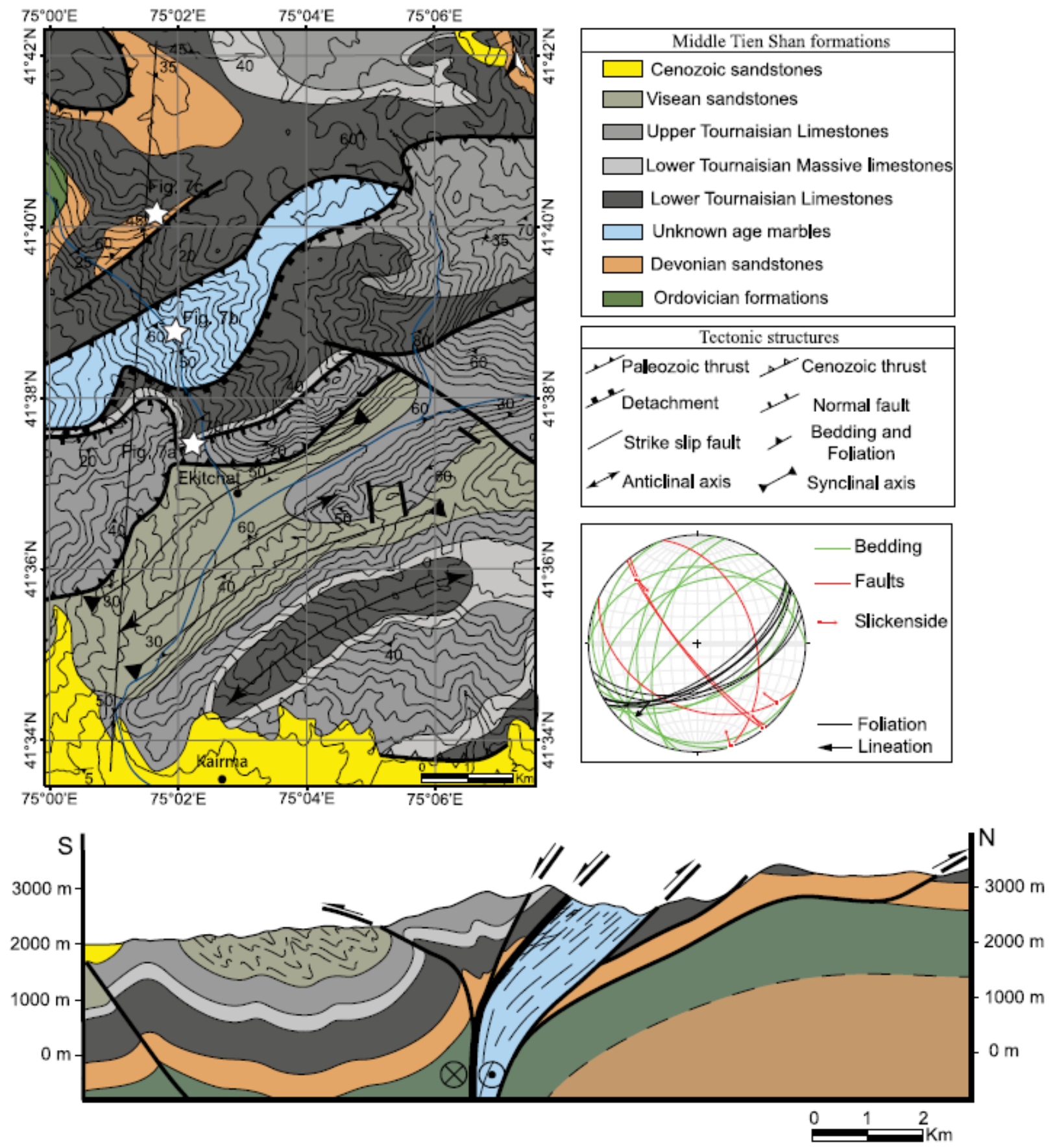

Fig. 6 

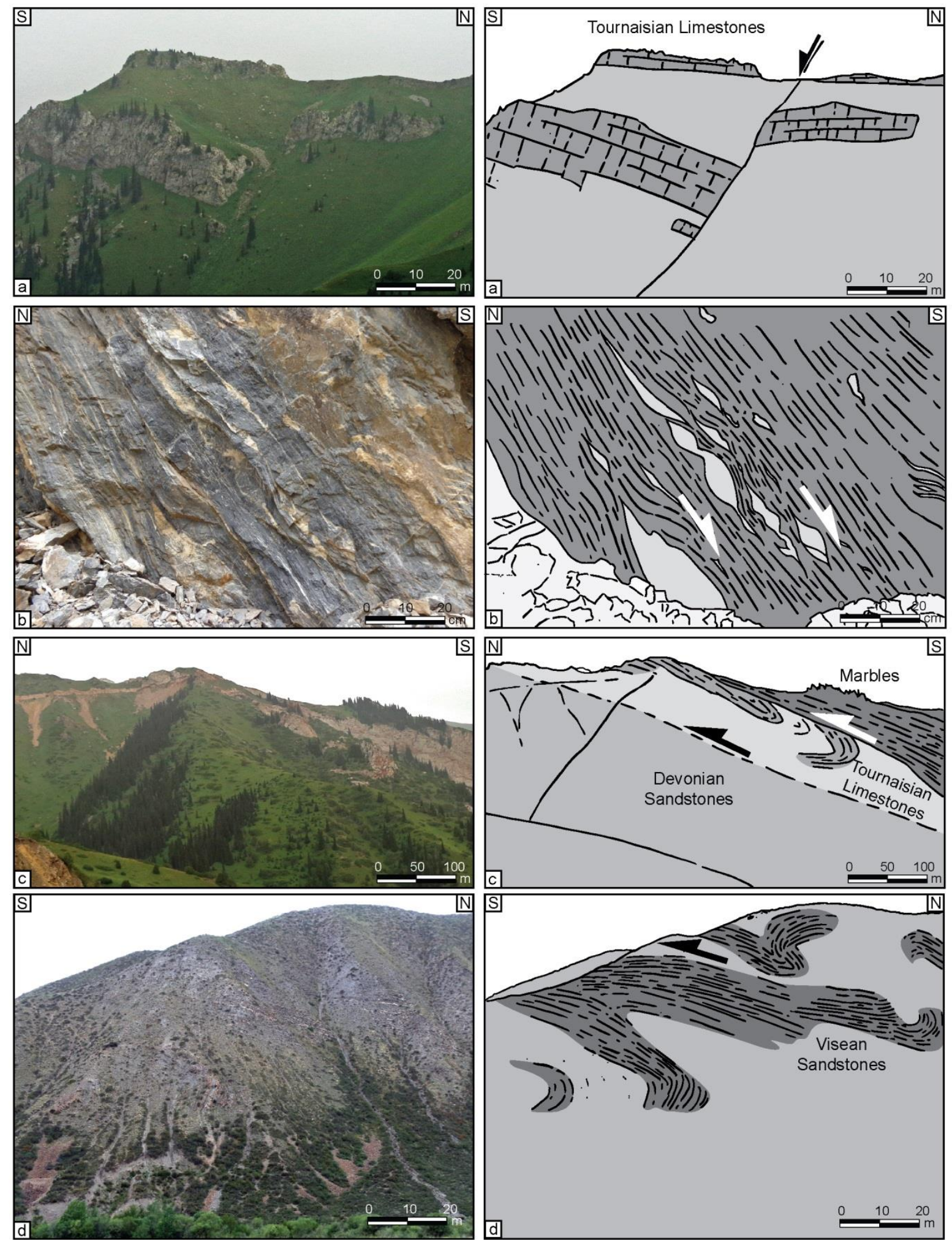

Fig. 7 

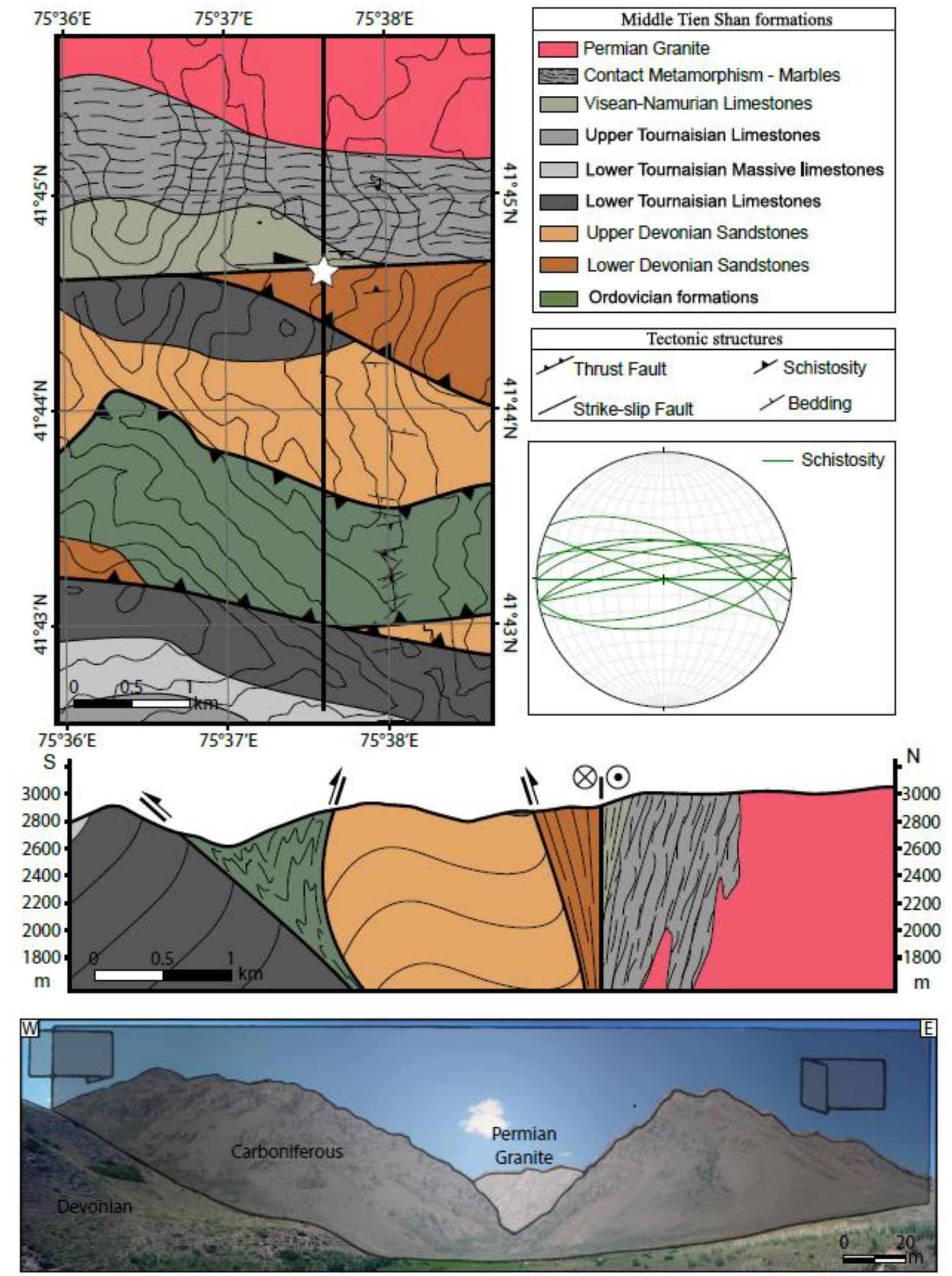

Fig. 8 

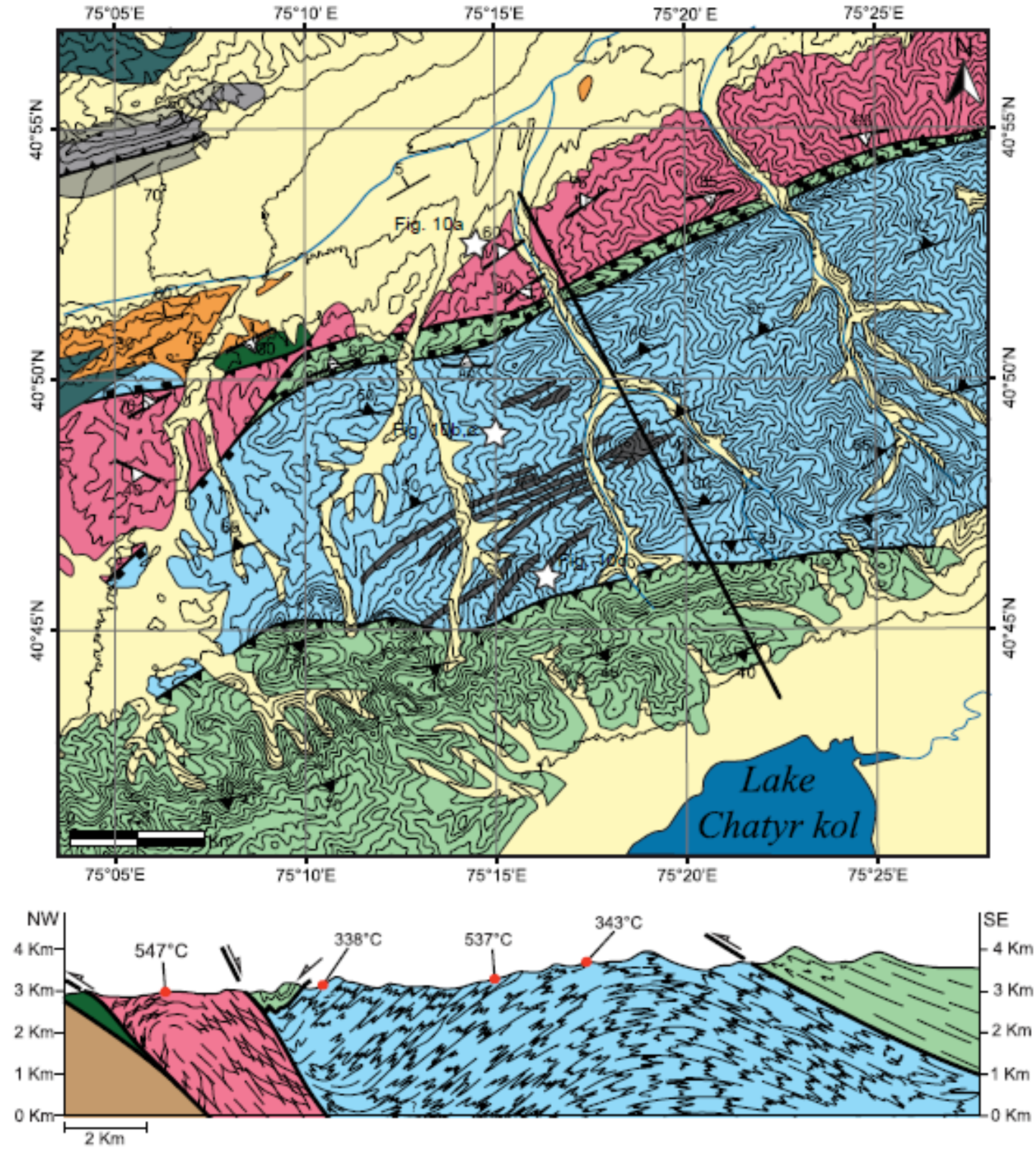

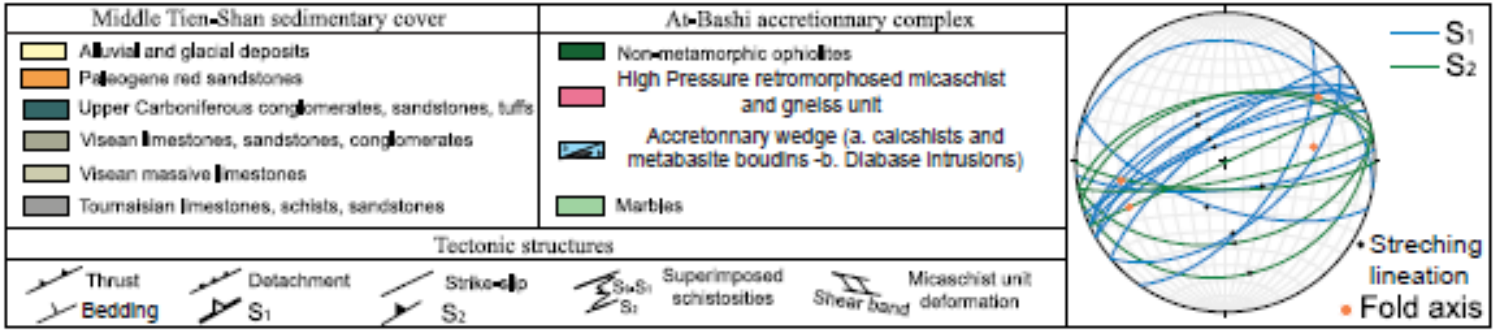

Fig. 9 

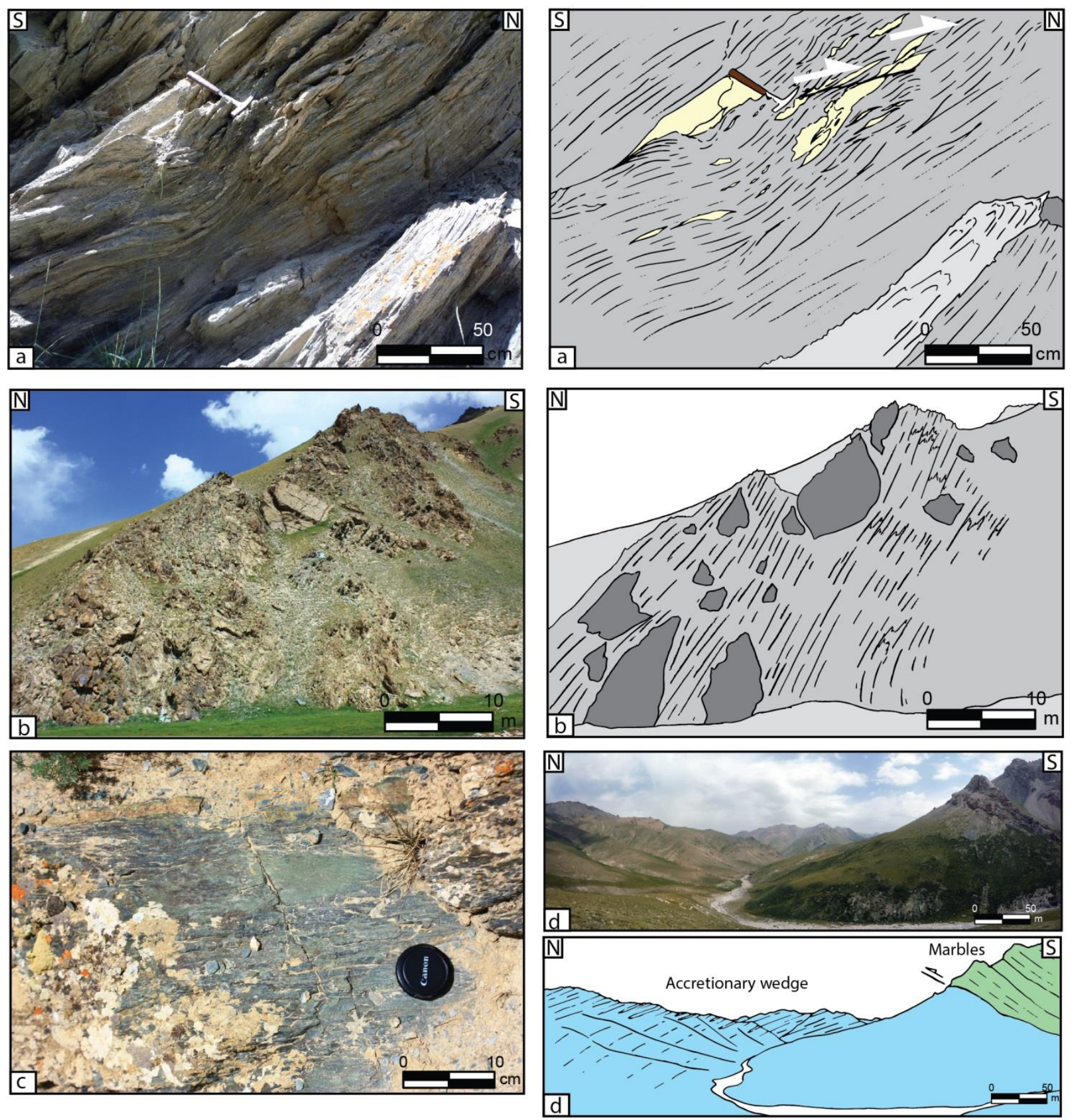

Fig. 10 

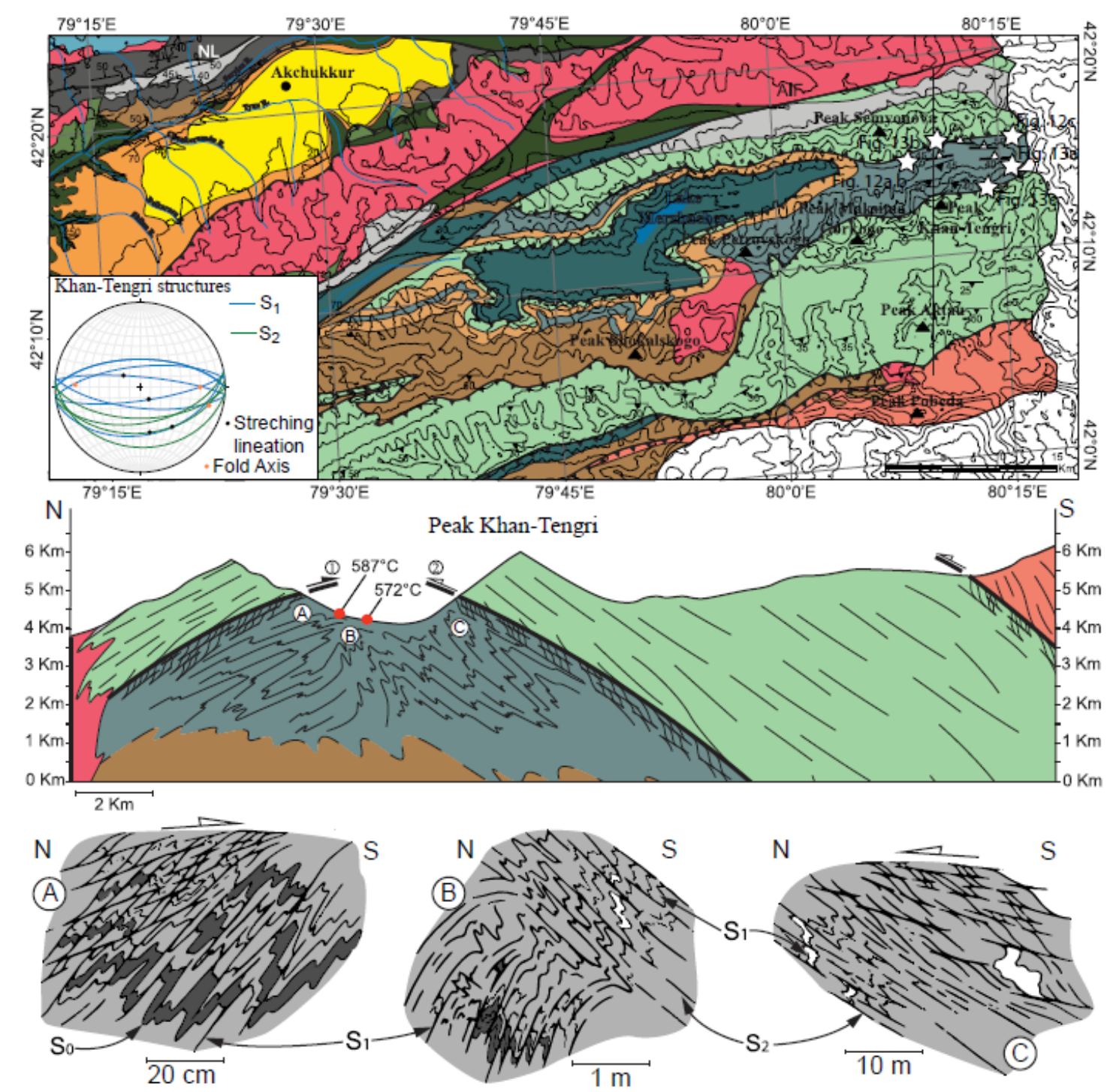

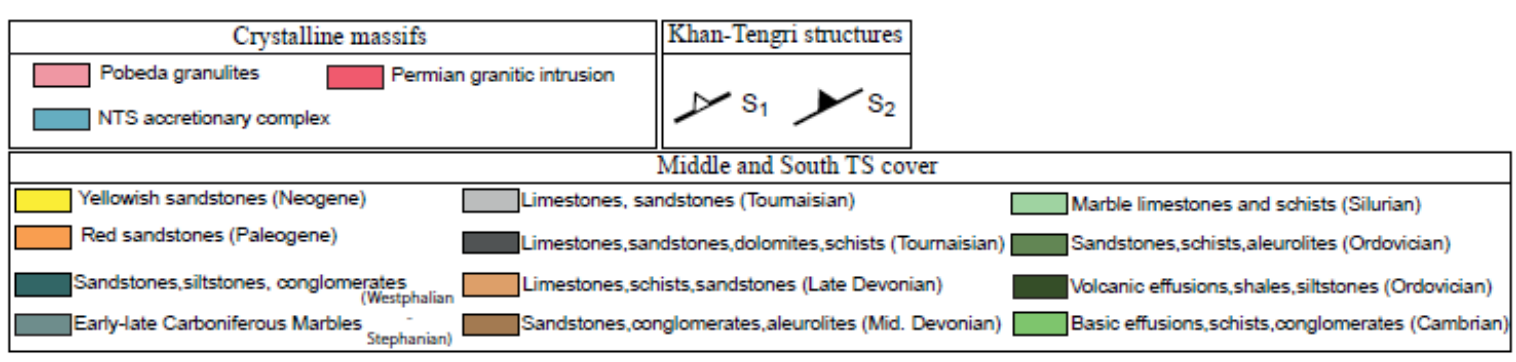

Fig. 11 

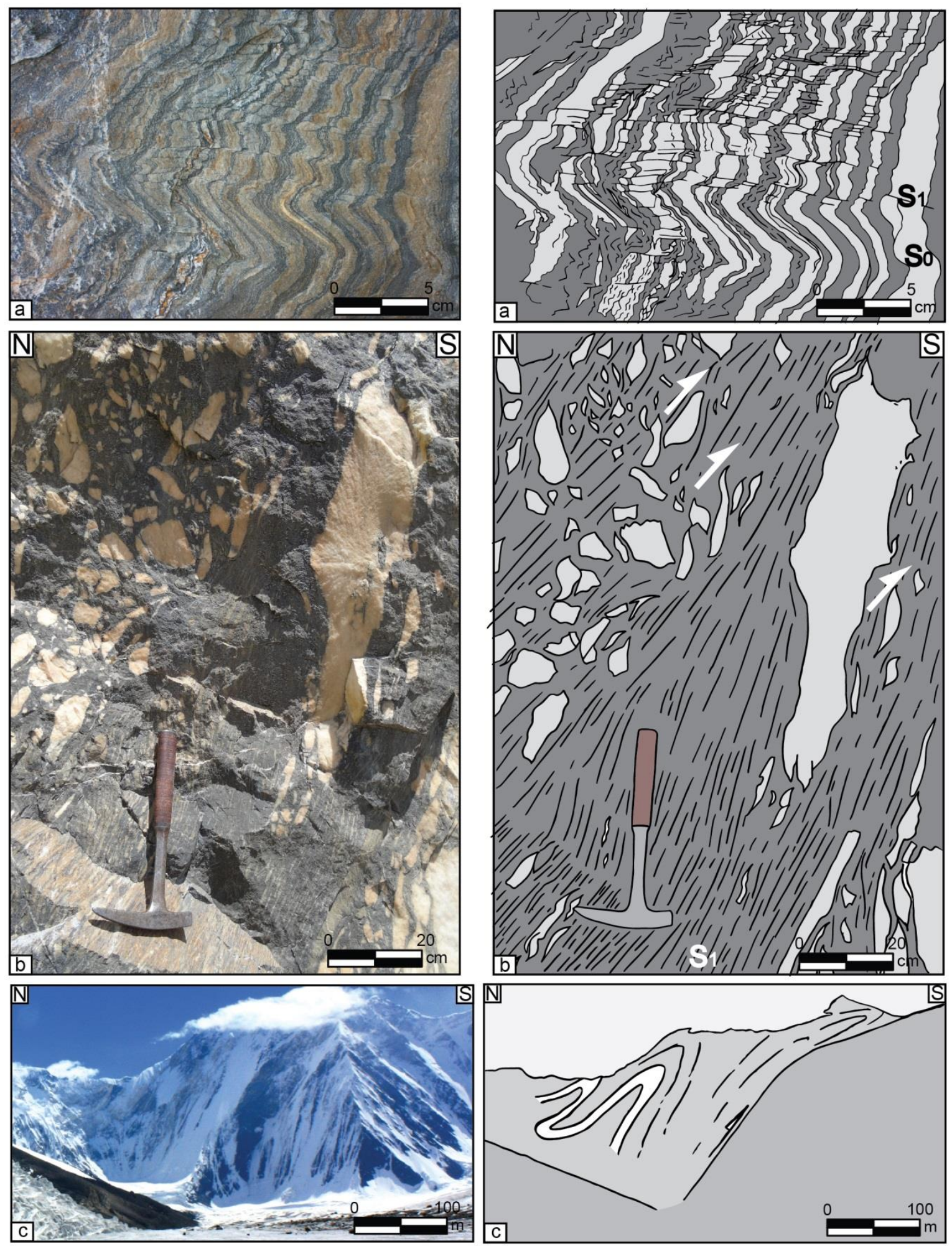

Fig 12 

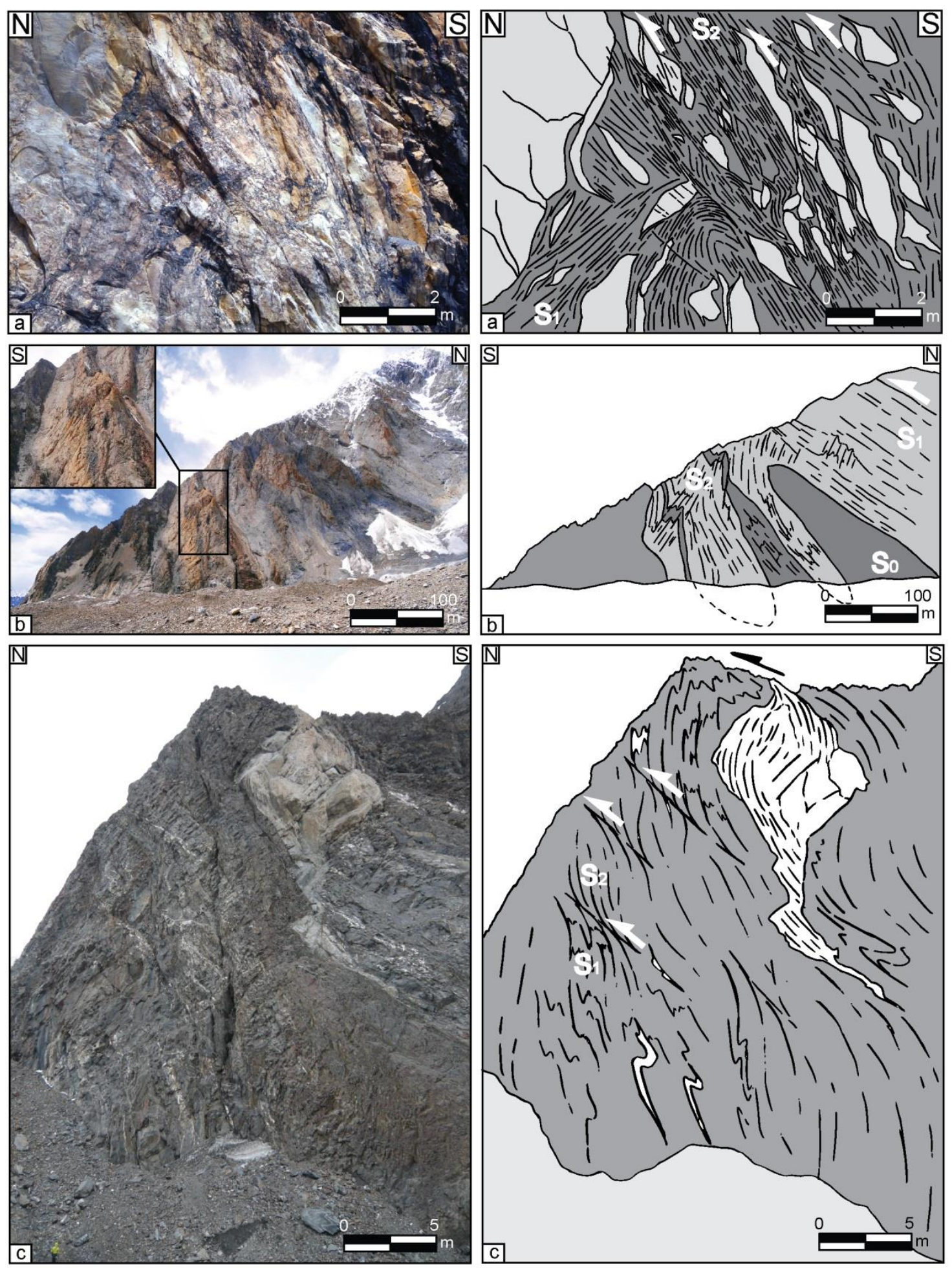

Fig. 13 


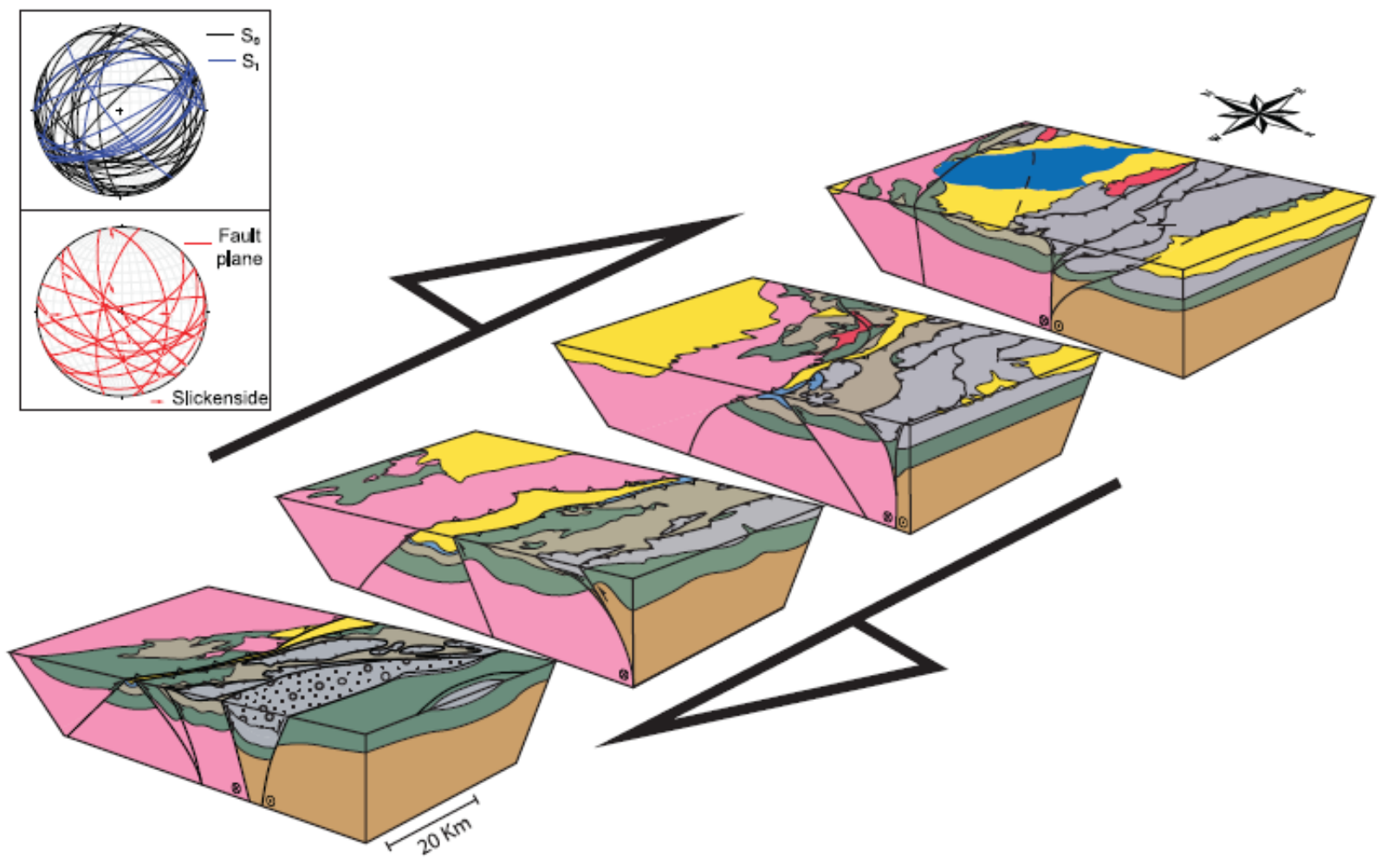

\begin{tabular}{|lll|}
\hline Legend: & & \\
$\square$ Magmatic arc (Ordovician) & Cenozoic basins \\
$\square$ Early Paleozoic cover & $\square$ Middle Tien Shan carbonate platform (Carboniferous) & Paleozoic thrust \\
$\square$ Song-Kul zone formations (Carboniferous) & $\square$ Alcaline magmatic rocks (Permian) & Cenozoic thrust \\
\hline
\end{tabular}

Fig. 14 


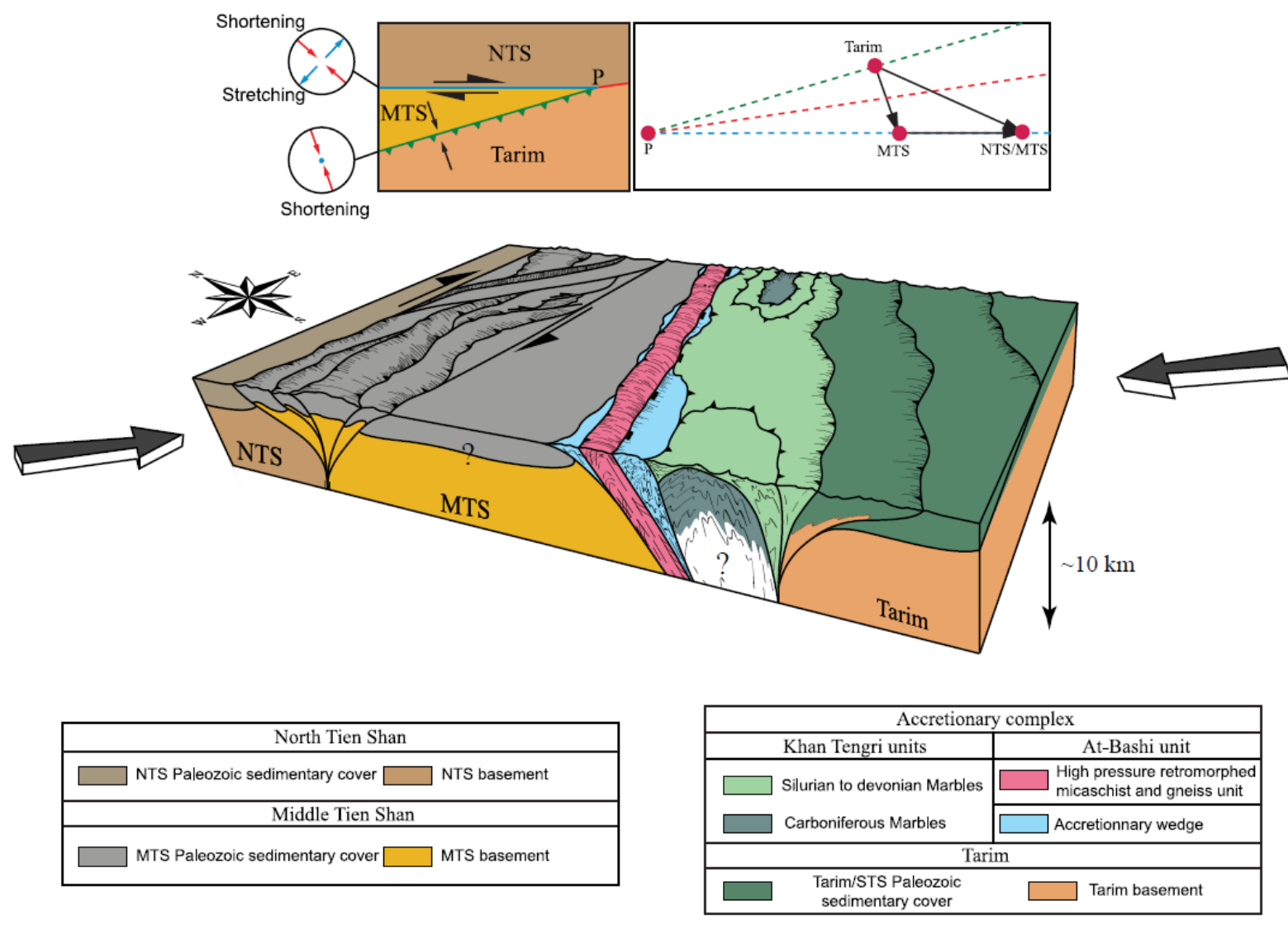

Fig. 15 
Table 1

\begin{tabular}{|c|c|c|c|c|c|c|c|c|}
\hline Sample & Rock & Longitude & Latitude & $\mathrm{n}$ & R2 mean & SD & Tmax mean $\left({ }^{\circ} \mathrm{C}\right)$ & $\mathrm{SE}\left({ }^{\circ} \mathrm{C}\right)$ \\
\hline KG-14-58 & Calcschist & 75,279 & 40,858 & 13 & 0,68 & 0,02 & 338 & 3 \\
\hline KG-14-64 & Micaschist & 75,288 & 40,843 & 18 & 0,23 & 0,06 & 537 & 7 \\
\hline KG-14-67 & Schist & 75,299 & 40,789 & 28 & 0,67 & 0,02 & 343 & 2 \\
\hline KG-14-18 & Marble & 80,179 & 42,254 & 7 & 0,12 & 0,05 & 587 & 9 \\
\hline KG-14-20 & Quartzite & 80,179 & 42,252 & 23 & 0,15 & 0,06 & 572 & 5 \\
\hline KG-11-43 & Micaschist & 75,266 & 40,879 & 20 & 0,21 & 0,04 & 547 & 4 \\
\hline
\end{tabular}




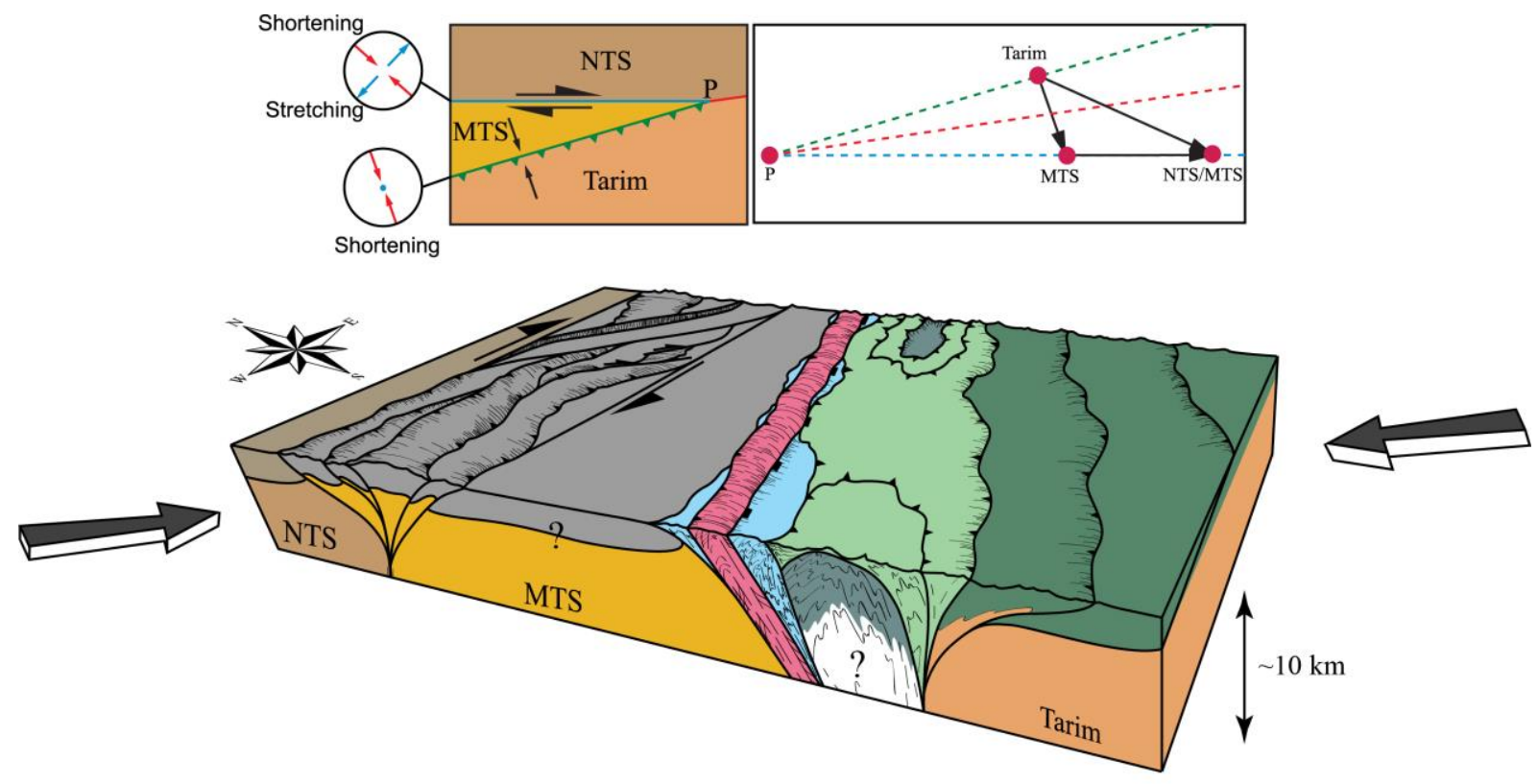

\begin{tabular}{|c|}
\hline North Tien Shan \\
\hline$\square$ NTS Paleozoic sedimentary cover $\square$ NTS basement \\
\hline Middle Tien Shan \\
\hline MTS Paleozoic sedimentary cover $\square$ MTS basement \\
\hline
\end{tabular}

\begin{tabular}{|c|c|}
\hline \multicolumn{2}{|c|}{ Accretionary complex } \\
\hline Khan Tengri units & At-Bashi unit \\
\hline \multirow{2}{*}{$\begin{array}{l}\text { Silurian to devonian Marbles } \\
\text { Carboniferous Marbles }\end{array}$} & $\begin{array}{l}\text { High pressure retromorphed } \\
\text { micaschist and gneiss unit }\end{array}$ \\
\hline & Accretionnary wedge \\
\hline \multicolumn{2}{|c|}{ Tarim } \\
\hline $\begin{array}{l}\text { Tarim/STS Paleozoic } \\
\text { sedimentary cover }\end{array}$ & Tarim basement \\
\hline
\end{tabular}

Graphical abstract 


\section{Highlights}

- Geological maps and cross-sections of the Middle and South Kyrgyz Tien Shan

- Structural data and deformation relative chronology in the Khan Tengri Massif

- Field and structural investigations along suture zones

- Highlighting of oblique collision between the Tarim and the Tien Shan 